\title{
Equal Treatment of Shareholders in Corporate Distributions and Reorganizations
}

\section{Citation}

Victor Brudney, Equal Treatment of Shareholders in Corporate Distributions and Reorganizations, 71 Calif. L. Rev. 1072 (1983).

\section{Published Version}

http://scholarship.law.berkeley.edu/californialawreview/vol71/iss4/9/

\section{Permanent link}

http://nrs.harvard.edu/urn-3:HUL.InstRepos:12967859

\section{Terms of Use}

This article was downloaded from Harvard University's DASH repository, and is made available under the terms and conditions applicable to Other Posted Material, as set forth at http:// nrs.harvard.edu/urn-3:HUL.InstRepos:dash.current.terms-of-use\#LAA

\section{Share Your Story}

The Harvard community has made this article openly available.

Please share how this access benefits you. Submit a story.

Accessibility 


\section{California Law Review}

Volume 71 | Issue 4

Article 9

July 1983

\section{Equal Treatment of Shareholders in Corporate Distributions and Reorganizations}

Victor Brudney

Follow this and additional works at: http://scholarship.law.berkeley.edu/californialawreview

\section{Recommended Citation}

Victor Brudney, Equal Treatment of Shareholders in Corporate Distributions and Reorganizations, 71 CAL. L. Rev. 1072 (1983). Available at: http://scholarship.law.berkeley.edu/californialawreview/vol71/iss4/9

This Article is brought to you for free and open access by the California Law Review at Berkeley Law Scholarship Repository. It has been accepted for inclusion in California Law Review by an authorized administrator of Berkeley Law Scholarship Repository. For more information, please contact jcera@law.berkeley.edu. 


\title{
Equal Treatment of Shareholders in Corporate Distributions and Reorganizations
}

\author{
Victor Brudney
}

\section{TABLE OF CONTENTS}

PAGE

I. Transactions Involving Distributions or ONLY INTERNAL REARRANGEMENTS OF PARTICIPANTS ......... 1076 A. Dividend Distributions.......................... 1076

B. Liquidating Distributions and Going Private .......... 1078

1. Liquidating Distributions ..................... 1079

a. Entitlement to Equal Treatment ............. 1079

i. Distributions which produce losses for minority shareholders .................. 1080

ii. Distributions which apparently leave minority shareholders no worse off ................ 1082

b. Implementing the Requirement of Equal

Treatment .............................. 1090

2. Going Private ............................ 1091

C. Parent-Subsidiary Mergers ...................... 1098

1. Entitlement to Equal Distribution ............... 1099

2. Implementing the Requirement of Equal Treatment ................................... 1102

D. Corporate Purchase of Its Own Shares............. 1106

E. Summary .................................. 1114

II. Third Party Transactions...................... 1115

A. Arm's-length Mergers ........................ 1115

1. Mergers After Negotiated Sales by Controllers ..... 1115

2. Two-step Takeovers ......................... 1118

B. Sales of Control ............................ 1122

III. Collateral Benefits ........................... 1126

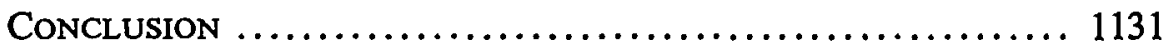




\title{
Equal Treatment of Shareholders in Corporate Distributions and Reorganizations
}

\author{
Victor Brudney†
}

Corporate law and academic comment addressing the proper division of assets of publicly held corporations among noncreditor claimants have been primarily concerned witl management's diversions of corporate assets to itself at the expense of stockholders. ${ }^{1}$ Less frequently noted, but by no means infrequently occurring, are the probleins generated by the diversion of corporate assets to majority or controlling stockholders ${ }^{2}$ at the expense of otlier stockholders of the same class. ${ }^{3}$ Whether the issue derives from the relationship of parent and subsidiary corporations or from transactions involving individual shareholders, probleins arise in a wide variety of contexts as to the

$\dagger$ Weld Professor of Law, Harvard University. B.A. 1937, M.Sc. 1937, College of the City of New York; LL.B. 1940, Columbia University. I am indebted to Timothy T. Casady for helpful research assistance and to Lucian $A$. Bebchuk for valuable criticism.

1. For example, management may divert corporate assets to itself by way of self-dealing, use of corporate property, taking of corporate opportunities or the like. The "agency costs" of monitoring and preveuting such behavior have been addressed by economists, see, e.g., Fama, Agency Problems and the Theory of the Firm, 88 J. POL. Econ. 288 (1980); Jensen \& Meckling, Theory of the Firm: Managerial Behavior, Agency Costs and Ownership Structure, 3 J. FIN. EcoN. 305 (1976), and lawyers, see, e.g., Anderson, Conficts of Interest: Efficiency, Fairness and Corporate Structure, 25 U.C.L.A. L. REv. 738 (1978). The law policing such costs is a primary component of basic coporate law courses.

2. The owner of $5 \%$ or $10 \%$ of the outstanding voting power may possess control. He need not own an absolute majority. For purposes of this Article, any block of stock which is sufficieut to control in fact will be called controlling and its owners may be referred to as a inajority. Those mvestors who are not part of the group of owners of the control block will be referred to as minority imvestors, even though in the aggregate they may own a majority of the stock.

3. This problein differs from a determination of the proper distribution of assets between two or more classes of investors whose investment contracts explicitly prescribe different interests in the enterprise, e.g. cominon stock and preferred stock with respect to dividend payinents or arrearage cancellation, see Brudney, Standards of Faimess and the Limits of Preferred Stock Modifications, 26 RuTGERs L. Rev. 445 (1973) [hereinafter cited as Brudney, Preferred Stock Modifications], or bondholders and stockholders with respect to insolvency or other reorganizations, see Blum, The Law and Language of Corporate Reorganization, 17 U. CHI. L. REv. 565 (1950); Blum, Full Priority and Full Compensation in Corporate Reorganizations: A Reappraisal, 25 U. CHI. L. Rev. 417 (1958); Brudney, The Investment Value Doctrine and Corporate Readjustments, 72 HARv. L. REv. 645 (1959); Clark, Fair and Equitable Reorganizations of Investment Companies, 53 B.U.L. REv. 1 (1973). In such cases, each class seeks to cause a rearrangement of participations in corporate assets which will inaximize value to it-generally at the expense of other classes. See, e.g., Broad v. Rockwell International Corp., 642 F.2d 929 (5th Cir.), cert. denied, 454 U.S. 965 (1981); Honigman v. Green Giant Co., 309 F.2d 667 (8th Cir. 1962), cert. denied, 372 U.S. 941 (1963); Zahn v. Transamerica Corp., 162 F.2d 36 (3d Cir. 1947). 
proper distribution of assets or sharing of new participations between controlling common stockholders and the remaining common stockholders. ${ }^{4}$

Appropriate solutions for these problems turn on the validity and meaning of two propositions which, in general terms, are part of the received learning about publicly held corporations. First, all shares of a particular class (e.g., common stock) are to be treated as homogeneous claims on enterprise wealth. Each share represents the same claim on corporate assets, imcluding expected returns, as each other share. Therefore in any distribution of assets or alteration of participations in the enterprise each shareholder should receive equal amounts or participate equally per share with each other investor. Second, it is the duty of management (and of majority stockholders in instructimg management or voting on management's decisions) to make decisions with respect to use of corporate assets or finance which are designed to maximize enterprise value consistently with the investment contract and with externally imposed legal constraints.

Conflict between the pressures to maximize enterprise value and to accord equal treatment to investors is reconciled in part through the investment contract. 5 The question is to what extent, in the absence of

4. Controlling stockholders, like managers, presumably act like economic agcnts seeking to maximize the return to themselves-even at the expense of other stockholders. Controllimg stockholders may be management or they may simply install a managemcnt which does their biddimg or what it beheves to be appropriate to serve the controllers' special interests. In either case, the temptation to divert common assets to the controllers at the expense of the other stockholders is the inevitable concomitant of "control." Most transactions require the intitiative, or at least the approval, of management and directors. It is assumed here, for ease of discussion, that management and directors serve the special interests of articulate controllers, whether or not the controllers are the persons who constitute management or the directors.

It is to be noted, however, that management and directors in authorizing use of corporate assets or directing corporate transactions are said to owe their obligations to the corporation, and not, at least at the expense of the corporation, to particular stockholders, or to one group of stockholders rather than another. See Delano v. Kitch, 663 F.2d 990, 998 (10th Cir.), cert. denied, 456 U.S. 946 (1981); H. Ballantine, Corporations $\$ \S 43$, 72a (2d ed. 1946); W. CARY \& M. Eisenberg, Cases and Materials on Corporations 150-53 (5th ed. 1980); H. HenN, Law of CorPORATIONS §§ 232, 235, 240 (2d ed. 1970); R. Stevens, Corporations § 143 (2d ed. 1949); Knauss, Corporate Governance-A Moving Target, 79 MiCH. L. Rev. 478, 487-88 (1981). As a consequence, im litigation challenging particular transactions as favoring controlling stockholders, the legal questions are generally addressed to whether the asserted managerial behavior improperly diminishes, or fails to enhance, corporate wealth while conferring a collateral or added benefit on controlling stockholders. See, e.g. , Complaint, Harman v. Masoneilan Int'l, Inc., 442 A.2d 487, 490 (Del. 1982) (No. 207, 1980). See infra note 179. To recognize management's or directors' obligations to the corporation does not deny their fiduciary obligations to individual shareholders in personal dealings between inanagement, them, and the shareholders. See N. LATTIN, CorpoRATIONS $\$ 81$ (2d ed. 1971).

5. The corporate capital structure, for example, may accommodate the pressure for equahity and the pressure to maximize enterprise value by allocating different risks and rctums to differcnt securities. Holders of senior securities sacrifice equality of return for safety; holders of common stock sacrifice safety for the possibility of greater gain and the opportunity to maximize cnterprise 
explicit consent to unequal treatment in the investment contract, the law should respond to the claim for maximization of enterprise value at the cost of equality among common stockholders of publicly lield corporations. That question ${ }^{6}$ and the import and validity of the two underlymg propositions will be examined in the contexts in which distributions and rearrangements of participations most frequently occur: (1) transactions which involve principally internal rearrangeinents among existing participants such as dividend or liquidation distributions, going private transactions, parent-subsidiary mergers or stock repurchase programs; and (2) transactions requiring participation by third parties, such as arn's-lengtl mergers, two-step inergers, or sales of control. ${ }^{7}$

In addressing these questions, two other inquiries are also involved. The first is whether substantively equal treatment-i.e., distributing assets or new participations of equal value-requires formally identical treatment. If sucli treatment is required, it is presumably required only instrumentally-as a necessary, or perliaps the most effective, way of assuring substantive equality. To characterize formally identical treatment as "instrumental" is not to deny its importance, however. Indeed, the link between formally identical treatment and substantively equal treatment is so close that some who urge disparate formal treatment seek expressly to justify substantive inequality. ${ }^{8}$ Others tend to scant the substantive equality problem and focus on the "excessive" cost of a rule of formally identical treatment. ${ }^{9}$ To reject such a rule, lowever, imposes other costs on achieving equality: the costs of monitoring self-dealing transactions on a case-by-case basis to

value. But when the conflict between equality and maximization pits one set of common stockholders against the others, the investment coutract does not expressly stake out the limits of the claim for maximization.

6. The question whether to impute investor consent ex ante to a majority decision which ultimately treats members of the class unequally (to the advantage of the majority and disadvantage of the minority) raises different issues than does the question whether to impute investor consent to a majority decision to yield the entitlements of each member of the class in the interest of interclass settlement. See, e.g., Aladdin Hotel Co. v. Bloom, 200 F.2d 627 (8th Cir. 1953); Goldman v. Postal Tel., Inc., 52 F. Supp. 763 (D. Del. 1943); H.R. REP. No. 595, 95th Cong., 1st Sess. $221-24$ (1977) (imterclass yielding in the context of the new Bankruptcy Act); Brudney, Preferred Stock Modifications, supra note 4, at 447-48.

7. Although it is largely theoretical, the question of equal treatment of stockholders may arise in the context of managerial control in the absence of dominant stockholders. The issues in that context involve management's duties in the face of conflicting stockholder preferences, rather than the issues of overreaching or misappropriation by one group of stockholders at the expense of others. See infra text accompanying notes 167-72.

8. See Easterbrook \& Fischel, Corporate Control Transactions, 91 YALE L.J. 698 (1982).

9. See, e.g., Hetherington, When the Sleeper Wakes: Reflections on Corporate Governance and Shareholder Rights, 8 Hofstra L. REv. 183, 233-54 (1980); Wolfson, A Critique of Corporate Law, 34 U. MIAMI L. REv. 959, $985-86$ (1980). 
determine substantive equality in the absence of reliable market prices, and of litigating to enforce such equatity.

The problem of equal treatment also implicates the consequences of corporate decisions that enhance the personal wealth of some stockholders by way of tax benefits or other personal preferences without adding to corporate wealth. ${ }^{10}$ Formally identical treatment of shareholders inay accompany a use of corporate assets that favors the personal wealth of controllers at the actual, or perliaps potential expense of the noncontrollers, or possibly at no cost to them. ${ }^{11}$ If the collateral, but real, impact of the corporate action adds to some shareholders' personal wealth but not equivalently to corporate assets or to the personal wealth of other stockholders, what relief, if any does a rule of equal treatment require?

Transactions InVOlving Distributions OR ONLY INTERNAL REARRANGEMENTS OF PARTICIPANTS

\section{A. Dividend Distributions}

The governing law requires substantively and formally equal treatment of shareholders in dividend distributions. When dividends are paid to members of a single class of shareloolders, each shareholder must receive an amount equivalent to that paid to the other members of the class. The corporation statutes of inost jurisdictions are not ex-

10. The "value" of an aliquot portion of the enterprise represented by a share of its common stock may be said to depend not only upon the value of the enterprise, but also upon the personal tax positions, portfolios, or other economic requirements of the individual investors involved. If eacli investor were concerned only with the sum of the distributions he receives and the remaining value of his slare of the enterprise there would be little reason for considering the impact of different managerial decisions on different stockhoiders. But each investor takes additional factors into account. He assesses the impact of the form which the distribution takes or the mcreased value of the security le receives on his total wealth, in the light of his individual tax position, portfolio, or other personal preference.

Thus, a dividend payment may be inade or withheld at the cost of an increase in corporate wealth, but it may favor particular stockholders whose personal income tax position is advantaged by the corporate decision. On anotlier level, a sale of assets or merger may be recommended by management or forced by majority stockholders at a price in sliares of one buyer which is less than another potential buyer is willing to pay in cash-to the tax and economic benefit of some stockholders and at the cost of others.

11. The problems that arise in relating inajority decisions about common property to the individual preferences of the constituents sliaring claims on the common property have been the subject of considerable inquiry. K. ARrow, Social Cholce and Individual Values (2d cd. 1963); J. Buchanan \& G. Tullock, The Calculus of Consent: locical Foundations of Constitutional Democracy ch. 6 (1962); M. Olsen, The locic of Collective Action (1977). However intractable these problems are in the context of the governance of society-with its manifold goals - they become more inanageable as the range of possibie goals is narrowed. In corporate decisions, at least if the single goal is maximizing the value of collective assets, closer meshing of individual preferences and collective choices becomes feasible. 
phicit on the subject, and corporate charters do not generally spell out the matter in detail. ${ }^{12}$ But, the case law leaves hittle doubt that, although meinbers of the class inay be given a choice, none inay be required to accept payinent different in form or ainount than is offered to the others. ${ }^{13}$

As a general proposition, a rule that assures substantive equality of dividend payments offers common stock investors a higher return per unit of risk, and society a less costly vehicle for obtaining capital, than a rule that permits indeterminately differential payments of common stock dividends. It also can reasonably be said to conform to public imvestors' cxpectations. Without a prescribed arrangement for equality of dividends the potential minority or disfavored investor would have no control over when management or a majority could, and no sense of when it would, allot inore per share to some stockholders than it allows

12. Typical statutes simply provide that the board of directors may declare and pay dividends to stockholders. See, e.g., Del. Code ANN. tit. 8, § 170 (1975); N.Y. Bus. CorP. Law $\S 510($ a) (McKmney 1963). When legislatures wish to permit the parties to change the assumption of equal treatment, as with preemptive rights, explicit language is used. See Del. CoDE ANN. tit. $8, \S 102(\mathrm{~b})(3)$ (1975). Cf. MOdel Business CoRP. ACT $\S 33$ (1979) (comparable treatment of voting rights per share).

Charter provisions in form books sometimes provide explicitly for proration of dividends for both common, K. Pantzer \& F.H. O'Neal, The Drafting of Corporate Charters and BYLaws I16 (ALI Handbook C 1951), and preferred, C. IsRaels, Corporate Practice 391 (1963); C. Israels \& R. Gorman, Corporate Practice 107 (1962), stock.

Corporate charters may possibly permit distinctions within a class. See, e.g., Del. CODE ANN. tit. 8, § 170 (1975). Cf. Providence \& Worcester Co. v. Baker, 378 A.2d 121 (Del. 1977) (a charter provision which provides for differeut voting rights withm a class is valid). But unless the charter permits directors to exercise their discretion in allocating participations to some unspecified members of the class but not to others, no serious issue is raised; the act of contracting expressly for a distinction that does not give directors discretion with respect to distributions to individual shareholders may appropriately be deemed to create two separate classes of stock.

13. See Twenty Seven Trust v. Realty Growth Investors, 533 F. Supp. 1028, 1040 (D. Md. 1982); Redhead v. Iowa Nat'l Bank, 127 lowa 572, 575-76, 103 N.W. 796, 798 (1905); Godley v. Crandall \& Godley Co., 153 A.D. 697, 707-09, 139 N.Y.S. 236, 244-45 (1912), modified on other grounds, 212 N.Y. 121, I05 N.E. 818 (1914); $f$. State v. Baltimore \& O.R.R., 6 Gill 363 (Md. 1847). See generally $11 \mathrm{~W}$. Fletcher, Cyclopedia of the Law of Private Corporations \$ 5352, at 723-28 (1971). But cf. Lewis v. H.P. Hood \& Sons, Inc., 331 Mass. 670, 121 N.E.2d 850 (1954) (allowing redemption of a portiou of common stock).

The requireinent of equal treatment is not only implicit in corporation statutes, but is also embraced, if not required, by fiduciary principles. To be sure, the majority's power to use the assets of all the investors was not delegated to it by the investors as to an officer or director. Indeed, the emergence of a coherent majority may be entirely unexpected by investors. Moreover the majority is itself a substantial owner of the common property. Hence, the risks the majority takes in operating or selling those assets affect it more than they might a trustee, an executive or an agent. And its right to participate in decisionmaking im those matters is not less than that of other investors. But because the size of its holdings gives it effective power in decisionmaking with respect to others' assets, some restrictions on its power, by analogy to tlose restricting a trustee or agent, are appropriate. Those restraints need not be as rigorously categorical as in the case of trustees or agents. See Anderson, supra note 1, at 790. The question is to wliat extent those restrictions should prohibit controllers from umilaterally appropriating a disproportionate share of the assets, where the value of the assets may be enhanced by the controller's policies. 
to a minority. In the absence of some contractually or legally imposed minimum allocation to each stockholder, the entire enterprise could be diverted to the others.

Such a level of risk would be, if not intolerable, at least very costly. It would be more costly than it would be worth unless it were necessary to assure some expected gain to society and were accompanied by an mcrement to the potential minority. It is difficult to envision either consequence resulting from a rule allowing discretionary allocation of dividends. ${ }^{14}$ Given the present state of our knowledge, the higher return per unit of risk required to induce investment in such a regime is a cost which appears to outweigh any compensating gain for society. This conclusion is supported, if not demonstrated, by the probability that issuers and underwriters offering securities would prefer a rule of equal treatment in dividend payments to a rule of discretionary treatment that would require explicit description to investors of the risks of disparate treatınent. ${ }^{15}$

If the governing principle requires that dividend distributions be substantively equal there is rarely reason to tolerate any difference in the form of the dividends distributed. To allow one group to be given cash and another group property (e.g., stock in the portfolio of the distributing company, a building, or some other item not in the form of cash) creates the possibility, if not the probability, of substantive inequality. Prudence, if not principle, counsels forbidding such formally different treatment. The temptation to differentiate substantively in favor of the majority is obvious. To allow such formal disparity would impose on minority recipients the cost of ascertaining whether the distribution concealed a substantive disparity, and the cost of enforcing the equal division of any gains realized by the majority.

\section{B. Liquidating Distributions and Going Private}

A different question is presented if an increase in the aggregate amount distributable to, or in the aggregate wealth of, all stockholders depends upon a decision which will only be made by the majority if it

14. Disparate dividend payouts are not needed to encourage investors to monitor management. Cf. text accompanying note 146.

15. Cf. N. Buchanan, The Economics of Corporate Enterprise $455-59$ (1940) (full disclosure may have a deterrent effect on investment). In theory, legal arrangements could permit management or majorities to make discretionary disparate dividend distributions unless investors contracted expressly against such distributions, or for minimum payments. But as experienceparticularly with preferred stock and with antidilution clauses in convertibles-suggests, see, e.g., Katzm, Financial and Legal Problems in the Use of Convertible Securities, 24 Bus. LAw, 359, 36066 (1969); Brudney, Preferred Stock Modifications, supra note 4; W. CARY \& M. EISENBERG, supra note 3 , at 1144-62, it is impossible to contract against all contingencies and costly to try. Not only would such a contract be difficult to draft (as are antidilution clauses), but it would expose inves: tors to risks in operation (as preferred stockholders' experience shows). 
receives more than its pro rata share of the increase in wealth. As a practical matter, that question is unlikely to be presented by any more or less regular distribution of dividends during the continued operation of the firm. But, it can arise, and present substantially more complex problems of equality of treatment when a controlling group of individuals or a privately held parent corporation: (1) distributes the firm's assets on dissolution; or (2) initiates going private transactions. ${ }^{16}$

In the forner case, the problein arises if the control group distributes the corporation's real assets (generally as a going concern) to itself and an assertedly equivalent amount of cash per share to the minority public investors - either by dissolution or by merger with a duminy. In the latter case, the control group may cause the issuer to purchase its own stock by public tender offer and/or to merge the public investors out of the enterprise by forming a dummy corporation to which the issuer's real assets are distributed and cash is paid to the public stockholders. In each case, some gaims are asserted for the transaction, both to society and to minority investors. To determine whether to sacrifice the rule of equal treatment for those gams iniplicates the questions whether those gains are significant and depend upon a rule of unequal treatment, whether the costs of a rule of unequal treatment exceed those gains, and whether, in any event, considerations of fairness permit a rule of unequal treatment.

\section{Liquidating Distributions}

\section{a. Entitlement to Equal Treatment}

There is no doubt that both statutes and case law require equal amounts or values to be distributed per share to members of a simgle class upon dissolution of the enterprise. ${ }^{17}$ And while the matter is

16. It is possible, although improbable, for such disparate hquidating distributions or going private to be initiated by management in the absence of controlling stockholders. It is difficult to envision circumstances in which such transactions are likely to occur which offer grounds for making disparate distributions any more tolerable when initiated by management than when initiated by controlling stockholders.

17. Statutes occasionally require "ratable" payment of preferred shares in liquidation. See, e.g. , N.Y. Bus. CORP. LAW $\$$ 502(b) (McKinney 1963). The cases are somewhat more explicit. Kellogg v. Georgia-Pacific Paper Corp., 227 F. Supp. 719, 722 (W.D. Ark. 1964); Zimmerman v. Tide Water Associated Oil Co., 61 Cal. App. 2d 585, 143 P.2d 409 (1943); In re San Joaquin Light \& Power Corp., 52 Cal. App. 2d 814, 127 P.2d 29 (1942); cf. Lebold v. Inland Steel Co., 125 F.2d 369 (7th Cir. 1941), cert. denied, 316 U.S. 675 (1942), appeal following remand, 136 F.2d 876 (1943). See Borden, Going Private-Old Tort, New Tort or No Tort?; 49 N.Y.U. L. REv. 987, 990-93 (1974). And form books plainly contemplate that charters will provide for equal payments "per share." See C. IsRaels, supra note 12, at 393; K. PANTZER \& F.H. O'NeAL, supra note 12, at 116; G. Seward, Basic Corporate Practice 93 (ALI-ABA 1962).

The fact that statutes and investment contracts provide for amendment of contracts by majority vote does not preclude a rule of equal treatment. If such amendment provisions, whether in statutes or contracts, were construed to permit the majority to alter the equality terms for their 
largely academic and the cases ambiguous, ${ }^{18}$ there is good reason to require formally identical as well as substantively equivalent distributions. The conclusion-both with respect to distribution of equal amounts and with respect to identical formal treatment-may best be illustrated by examining various distributions which might be made by an enterprise with 100,000 shares of common stock outstanding, selling at $\$ 20$ per share and, all other things being equal, expected to continue so to sell.

i. Distributions which produce losses for minority shareholders. In the simplest scenario, the controller, an individual or group of private individuals, owns 50,000 shares, and causes the corporation to liquidate and dissolve. He distributes $\$ 16$ per sliare to each minority stockholder while he takes $\$ 24$ per share for himself. Since the dissolution has not resulted in any increment in value of the enterprise, there is no nore reason to tolerate any such disparity in the liquidation distribution than in the case of ordinary contmumg dividends. ${ }^{19}$

Should the result be any different if the enterprise value increases (becomes worth unore than its going concern value of $\$ 2,000,000$ ) in circumstances that require, or induce the controller to desire, its dissolution? For example, suppose the enterprise owns a building without which it can function only at a considerably less profitable level than in the past. The controller discovers a use for the building which entails added risk acceptable to all investors, but makes it worth $\$ 2,500,000$ and requires abandoning the business. Or suppose the firm's manage-

own benefit, there would be no limit to the minority's exposure to expropriation. A different problem is raised by the holdup powers of oue class of stock to force another class to yield by amendment in a distribution of assets. See, e.g., Goldman v. Postal Tel., Inc., S2 F. Supp. 763 (D. Del. 1943). In that circumstance the consent of a majority (or more) of the victims to the holdup is required. See, e.g., MODEL BusInEss CORP. ACT $\$ \S 59-60$ (1979). Amendment by a majority of a class for its own benefit does not offer victims even the protection of requiring their own consent.

18. See, e.g., Kellogg v. Georgia-Pacific Paper Corp., 227 F. Supp. 719, 722 (W.D. Ark. 1964); Zimmerman v. Tide Water Associated Oil Co., 61 Cal. App. 2d 585, 143 P.2d 409 (1943).

19. Rational investors would not consent to disparate sharing that might give them even less than they had before dissolution even if there were reason to beheve that such a disparate distribution would induce controllers to increase the size of the distributable pie. The mimority investors would likely be losers on every occasion and never share in any of the value made possible by their consent to disproportionate sharing. In such a hypothetical ex ante bargaming position, even if we assume that it is unknown who is, or may become, the controlling investor, and that therefore a rational investor would balance his possible losses with the possibility that he might share in the mulcting upon dissolution, the rational risk-averse investor will not choose a rule of disparate sharing. He will be affected by the uncertainty of whether he will become part of the control group and the uncertainty of the amount that the control group might appropriate from the minority. More important, with no requirement that the eventual controller condition dissolution on increasing distributable values, and no reason to beheve he will only effect disparate distributions when values are mcreased by, or as a part of, the dissolution, a rule permitting such distributions would be wasteful. It would increase risk without increasing gain. In short, social gain will not result from, and advance consent will not rationally be given to, such behavior. 
ment generates a readily implementable proposal for an additional product which is expected to produce a return (albeit at added risk) that will make the busmess worth $\$ 2,500,000$, net of the cost (which the firm is able to meet) of implementimg the proposal. ${ }^{20}$ Should the law permit the majority shareholders to dissolve the corporation and distribute the busmess to themselves (at $\$ 34$ per share) and cash (at $\$ 16$ per share) to the minority-i.e. to condition corporate acceptance of the proposal upon hiquidating disproportionately? It is hard to see why the fact that a higher value will accompany the transaction should enable the controller to condition the firm's realization of that increase on a diversion to himself that results in the minority receiving less than its predistribution value.

Disproportionate division in the liquidation context would increase the cost of capital no less than would disparate distribution of dividends. An investor mvesting in an enterprise which has a controlling stockholder group would understand that he would be subject to the risk of virtually complete expropriation by the controller. ${ }^{21}$ If he were to invest in an enterprise with widely dispersed stockholdings and no controlling stockholders, he would be exposed to the risk of soineone acquiring control, ${ }^{22}$ or of managerial arbitrariness. And since shares are freely transferable in a national market, the investor would have no way of knowing whether he would be, or would be permitted to be, a participant in the majority or favored group..$^{23}$ Faced with such uncertainty, the investor would raise his price for investing.

Moreover in theory, at least, it is not necessary to permit so unequal a division of the gains in order to induce the controller to move the assets to a presumably better use. If he captured all the gain froin

20. The hypothetical proposal does not reqnire capital unavailable to the firm, and it offers a "fit" with the firm's present business, so that the conventional "corporate opportunity" issues raised by the proposal are minimal.

21. Statutory restrictions on payment of dividends (whether by reference to earned surplus, balance sheet or other tests) offer some protection for common stockholders prior to dissolution; but even that protection is notoriously porous and not available on dissolution.

22. To the extent that federal and state legislation narrow the possibility of acquiring control to the tender offer, the consequence of that risk is mitigated by the potential controller's need to offer potential mimority stockholders a price. But the bidder's priee will refiect the fact that the target's stock is presumably selling at a price embodying the risk of being expropriated.

23. In theory, investors can reduce the risk of investing in a particular corporation by diversifying their portfohos. See Modigliani \& Pogue, An Introduction to Risk and Return: Concepts and Evidence (pts. 1 \& 2), Frn. ANALYSTS J., Mar.-Apr. 1974, at 68, May-June 1974, at 69. But such diversification is not available for the risks to minority investors in corporations which are controlled privately. Public investors cannot invest in other privately controlled corporations and hence cannot becoine the beneficiaries of diversion by other private controllers. To be sure, investors may invest in stocks of publicly held parent corporations and thus become beneficiaries of any disparate distribution the parents cause the subsidiaries to make to the parents. But that would require investors to add still another variable to their risk-return calculations. See infra text accompanying notes 82-83. 
the "better" use of corporate assets, ${ }^{24}$ he should not need or rationally be entitled to the added inducement of expropriating some of the minority's share of predissolution value.

ii. Distributions which apparently leave minority shareholders no worse off. Should the principle of equality be abandoned if the mimority is offered the protection of a requirement that the inajority give the minority, on dissolution, not less than its proportionate interest in the predissolution value of the enterprise? For exainple, should the majority be permitted, if it approves the proposal to make the corporate assets worth $\$ 2,500,000$, to distribute $\$ 1,050,000$ to the minority and keep $\$ 1,450,000$ for itself? Or should the principle of equality protect the minority and preclude the majority from taking more than its proportionate share?

The argument for departure from a rule of equal treatment is that, ex ante, rational minority investors should consent to such departure because they will be better off under a regime that offers them a share (however modest) in the gains; and that society will be better off because the assets will be put to a more productive use, at least if productivity is tested by their increased dollar value. But there is reason to beheve (a) that the realization of those gains does not, except perhaps to a margmal extent, require a rule of disparate treatment; (b) that those gams are outweighed by the costs of even so limited a version of a rule of unequal treatment, and (c) that considerations of fairness argue sufficiently powerfully for a rule of equal treatment to overcoine the uncertain, if any, excess of gain over cost from the contrary rule.

(a)

A disproportionate division is only justified if any gain, or better social use to be made of the assets, depends functionally on the controller receiving a disproportionate share. If the controller's claim to the "sweetener" rests merely upon his power to extort a toll for his consent to the project rather than upon a legitimate claim for coinpensation due to added risk or added effort in discovering or making the new use of the property, there is little reason to honor the claim. The risk attending the conversion of the buildimg or the new proposal for the use of corporate assets will be borne by all stockholders pro rata, not particularly by the controller. Hence, the controller, in accepting the proposal

24. He may claim that the value of his control block is more than his aliquot share of the enterprise value, either because it enables him to appropriate assets or perquisites improperly or because he can claim a premium on sale of control. Neither is an appropriate reason for allowing unequal sharing on liquidation, see infra note 160 , and certainly not if such sharing deprives the minority of the preliquidation value of their shares. 
or converting the building, does not take on any unshared risk which requires extra compensation, much less the open-ended kind of compensation which is contemplated by a rule of disproportionate sharing on a "no worse off" basis.

The gam resulting from the new use may be dependent upon the controlling stockholder sharing in it disproportionately if he imposes such sharing as a condition to his lending his efforts (as distinguished from risking his capital) to seeking or managing the new use. Entitlement to compensation for expenditure of his efforts does not equate with disproportionate sharing in gains. In any given case it is hard to determine the value of the controller's talents and efforts, or whether their expenditure is necessary to the discovery or successful exploitation of the new use, or whether he is simply attempting to assert his holdup power. But even if it is legitimately possible to tie the expected gain to the controller's effort and his resulting insistence upon unequal treatinent, the question is whether that potential for gam is worth the cost of permitting it.

In seeking to answer the question of how large a gain to society will be lost by a rule that discourages a controller from seeking or permitting improved uses of property from which he does not receive all, or the lion's share, of the gain, no very precise quantifications can be expected. Not only are there no adequate markets to calibrate such exchange decisions, but the variations in the alnounts for which different controllers will "settle" leave the problem unanswerable except in terins of direction. ${ }^{25}$ Some gains will not be realized, but the inagnitude of the resulting social cost is ambiguous.

(b)

For the minority imvestors to be "better off" under a rule of disparate treatment, they inust receive something of more value on dissolution than they had prior to dissolution. If imvestors are uncertain as to whether they are receiving more than they owned prior to liquidation, it would require significant social gains to justify such disparate treat-

25. If stockholders were offered the ex ante choice between a rule of equal sharing and a rule of disparate treatment, on a "no worse off" basis, they would not be without a reasonable basis for choosing the former. The controller will not turn down all gains or decline to seek them under a rule of equal treatment, particularly if he is paid the cost of his effort. See infra note 45 . To be sure, there is some marginal level of gain at which the controller would not undertake the new use if equal sharing were required-the level at which the new use produces less than the value of being able to exploit control both on a continuing basis and by sale at a premium. To the extent that the latter is forbidden and the former is more carefully policed, the level of gain at which the controller would balk is reduced. See infra note 160 . To the extent that transactions involve that level of gain or less, minority stockholders and society may lose by a rule of equal choice. 
ment since, ex ante, knowledge of that uncertainty would raise the cost of investing.

The amount by which shareholders are claimed to be "better off" is generally said to be the difference between the cash they receive on dissolution and the predissolution value, as evidenced by the market price of their stock. ${ }^{26}$ But that price does not automatically establish the value of the minority's interest. Nor does it automatically establish the equivalence of the cash distributed to the public and the value of the busmess retained by the controllers.

The mere fact of majority control throws a considerable shadow on the validity of the predissolution market price of the minority's stock as a measure of its value. That shadow is not incompatible with most acceptable concepts of an efficient market. The claims for the efficient market inay or may not, in general, be sufficiently established to underpm norms predicated on the "correctness" of stock market prices. ${ }^{27}$ The best established of those claims is predicated on the behavior of histed stocks or stocks of comparably sized firms; and in any event, it is rarely claimed that at all times all stock prices (even of listed stocks) reflect all relevant or material information about value. It is conceded that prices do not always reflect all "inside" information. ${ }^{28}$

26. Easterbrook \& Fischel, supra note 8, at 714-15. There is, of course, no certainty that even as so measured the minority will be given much "more." Controllers, acting unilaterally, are not likely to give the minority any more than the prevailing rule would require-enough to leave the minority slightly, but uncertainly, better off.

27. The claims for "efficiency" of the stock market are uncertain in scope and are not unchallenged in principle or einpirically. See L. Summers, Do WE REALly KNOW that FinanCIAL MarketS ARE Efficient? (Nat'1 Bur. of Econ. Research Working Paper No. 994, Sept. 1982); Foster, Briloff and the Capital Markets, 17 J. ACCT. ReseARCH 262, 268-69 (1979); authorities cited in Brudney, Efficient Markets and Fair Values in Parent Subsidiary Mergers, 4 J. CoRP. L. 63, 66 n.14 (1978). See also Lowenstein, Pruning Deadwood in Hostile Takeovers: A Proposal for Legislation, 83 ColuM. L. REv. 249 (1983), for a discussion of the possibility of siunple undervaluation by the securities markets and of possible differences in "cfficiency" betwcen the market for shares and the inarket for firms. The concept of efficient markets covers transactions on averagc. Any given transaction or set of transactions may depart radically froin the average. Such a departure is most probable in the case of transactions by controllers involving the stocks of their corporations when they contemplate going private, merging with subsidiarics, or repurchasing shares. See Brudney, supra, at 69-73; see also V. Brudney \& M. Chirelstein, Cases and MAterials ON CORPORATE FINANCE 964-67 (2d ed. 1979). Other imperfections, which are impervious to diversification, also affict the capital markets. See, e.g., C. HALEY \& L. SCHALL, THE THEORY OF Financial Decisions ch. 14 (2d ed. 1979); Modigliani \& Cohn, Inflation, Valuation and the Mar. ket, FIN. ANALYST's J., Mar.-Apr. 1979, at 24; Kahn, The Tyranny of Small Decisions: Market Failures, Imperfections, and the Limits of Economics, 19 KYKLOS 23 (1966); see also Arrow, Risk Perception in Psychology and Economics, ECON. INQUIRY, Jan. 1982, at 1-8.

28. See Fama, Efficient Capiral Markets: A Review of Theory and Empirical Work, 25 J. FIN. 383, 415-16 (1970); J. Lorie \& M. Hamilton, The Stock Market: Theories and Evidence 96 (1973). It las been suggested that the law of fraud, federal disclosure requirements, and the efforts of private seekers of infornation are able to assure investors adequate disclosure of such information so that price will reflect full value at the time of a liquidation by a controller, a parent-subsidiary inerger, or a going private transaction, $c f$. Easterbrook \& Fischel, supra note 8, 
That concession is significant in a context in which market price is, to a greater or lesser extent, within the control of the controlling stockholders, and therefore its "correctness" poses a continuing risk to the minority. That potential risk is accentuated because the majority has unrestricted control of the timing of the dissolution and associated transactions. Even in efficient markets, and without insiders' expectations of increase in enterprise value, stock prices can be temporarily manipulated in anticipation of dissolution. ${ }^{29}$ While federal and state disclosure requirements have narrowed the range for such manipulation, the minority is nevertheless put at an indeterminate, but not inconsiderable, risk that the measure of its entitlement under a rule of "no worse treatment" (i.e., market price) is disadvantageously flexible at the wish of the majority. And the uncertainty as to the value of the enterprise distributable on dissoiution ${ }^{30}$ enlarges that flexibility.

In view of these uncertainties, a rule of disparate treatınent would render the investor powerless to prevent a division of assets which leaves him either worse off than he was before dissolution (albeit in receipt of a price higher than the apparently "correct" market price), or

at 730-31 (arguing that banning going private transactions is not justified by the risk of exploitation of inside information); Hetherington, supra note 9, at 235 (arguing that disclosure requirements and appraisal rights can lead to a valuation of shares that is reasonable and protects the public). But the proposition is not self-evident. Indeed, it is hard to find evidence to support it. There have been suggestions that issuer tender offers (which may or may not involve controlling stockholders or implicate going private transactions) benefit offerees inore than nonsellers, but that open-market purchases by issuers beuefit nonsellcrs more than offerees. The evidence is ambiguous so far as going private transactions are concerned. And the short time spans involved in the studics leave open the question whether unrevealed prospects surface later. See M. Bradley \& K. Wakeman, The Wealth Effects of Targeted Share Repurchases (Sept. 1982) (unpublished manuscript forthcoming in volume 11 of the Journal of Financial Economics); Dann, Common Stock Repurchases: An Analysis of Returns to Bondholders and Stockholders, 9 J. FIN. EcoN. 113 (1981); Masulis, Stock Repurchase by Tender Offer: An Analysis of the Causes of Common Stock Price Changes, 35 J. Fin. 305 (1980); Vermaelen, Common Stock Repurchases and Market Signalling: An Empirical Study, 9 J. Fin. Econ. 139 (1981).

In any event, the suggestion that the law of fraud does or can compel adequate disclosure in such cases connes with a certain disingenuonsness from those whose passion is to narrow the disclosure required by the federal securities laws, apparently in the dispassionate interest of saving costs and increasing efficiency. See, e.g., Hetherington, supra note 9, at 247.

29. See Brudney, supra note 27, at 69-73; Penman, Insider Trading and the Dissemination of Firms' Forecast Information, 55 J. Bus. 479 (1982).

30. The indeterminate value of the share of the assets (i.e., the going business) which the controller elects to keep is evidenced in the courts' efforts to value businesses which have a flawed stock-market value. Difficulties of valuation and uncertainties of estimates are suggested by opinions in appraisal proceedings in the Delaware courts. See Note, The Dissenting Shareholder's Appraisal Remedy, 30 OKLA. L. Rev. 629, 640-41 (1977); Note, Valuation of Dissenters' Stock Under Appraisal Statutes, 79 HARv. L. Rev. 1453, 1468-69 (1966). Those difficulties are not lessencd by the valuation prescription in Weinberger v. UOP Inc., 457 A.2d 701 (Del. 1983). See also Brudney, supra note 27 , at 76 .

Since ascertaming the value of the going concern thus distributable to the majority requires eliciting information which the controller has about the future, quantifying the distribution is particularly difficult and costly for the outside minority. 
subject to a disproportionate division of values whose magnitude he cannot determine. No principle would enable a rational investor to predict in advance to how inuch of a diversion by the controller $(120 \%$, $45 \%, 20 \%$ ) of the investor's ahquot share of the ultimate increase he is consenting. Nor could he tell in advance how soon this diversion would be visited upon him. Both the risks of loss and the possibilities of gaim are likely, if not certain, to be shared disproportionately to the investor's disadvantage in magnitudes which have ambiguous limits on the downside and no assurance on the upside. Those limits are to be determined by the greed or sense of propriety of the controllers.

In a perfect world, investors could diversify and thus dilute the risk of being inulcted. In such a world, investors could estimate econonnic risks and returns, and fix a price for capital that would equihbrate with expected gains to themselves, if not to society. ${ }^{31}$ But in the imperfect world which inost investors inhabit, they cannot diversify away the risks of being mulcted by the controllers on dissolution. ${ }^{32} \mathrm{~A}$ rule setting predissolution value and hence market price as a floor on their recovery promises thein air. It does not assure them any gam from such transactions. And it gives controllers the incentive to dis- tribute less than aliquot shares even if ineasured on a predistribution value basis. Exposure to such risks would raise the cost of capital to an indeterminate extent. ${ }^{33}$

A rule of unequal treatment would also conduce to waste. It creates the possibility, by no ineans remote, that the controller's concern with the enterprise's value - and the nnarket price of its stock-will be diluted to the extent that his share of any distributable value can be satisfactorily increased. To be sure, the controller will not purposely conduct the firm's affairs so as to diminish its value. But, if the controller's pursuit of enterprise gain is mixed with concern about how to assure a disparate return to himself, energy which in theory should be spent only on the forner is likely to be diverted in part to the latter. And the temptation to engage in control transactions which permit such diversion contains the seeds of utterly wasteful transaction costs which are not offset by social gains of any sort.

31. However, social waste is likely if the cost of capital must be determined by discounting for uncertainties (the mulcting possibilities) whose variance should rationally be greater, or at least more difficult to measure, than the variance of expected cconomic returns from the distributed asset; or if the requircd return for public investors includes a component not required or offset in the economic return expected by the acquirer of the distributed asset.

32. By definition, the risk of being dissolved by a private controller is nondiversifiable. With regard to parent subsidiary transactions, the problem of diversification is discussed at infra text accompanying notes 81-84.

33. To be sure, there are limits to feasible market manipulation. Hence, with a more or less finite estimate possible, it is open to the investor, ex ante, to seek to factor the consequences of potential inanipulation into the cost of capital and to seek a higher return on his imitial investment. 
In sum, the costs of a rule of unequal treatment are not small. It is difficult to envision the magnitude of gains to society which would be necessary to offset that cost. It is even nuore difficult to see that such gains depend on permitting controllers to take a disproportionate rather than an aliquot share of the gains.

(c)

Whether or not considerations of efficiency counsel a rule of equal treatment, considerations of fairness and distributional policy argue against a departure fron that rule, at least where disparate treatment of stockholders is a function of decisions by a control group to allocate more than its pro rata share of corporate assets to itself. There is evidence, albeit not conclusive, to suggest that a rule of unequal treatinent will accentuate disparities of return between higher inconie and lower income mvestors in stocks, if imdeed it will not result in distributions from the latter to the former. ${ }^{34}$ In any event, in assessing the propriety of a rule of unequal treatment, or whether investors in a for-profit venture "ought" to consent to such a rule, it is not necessary to import considerations of altruism, or notions that underlie a sense of unfairness if benefits are not shared along with risks, or an ethic of "to each accordimg to his needs," however apposite they may be. Nor in view of investors' legitimate expectations of equal treatment is it necessary to press broader moral arguments for equahity. ${ }^{35}$

As an empirical matter, it is probable that investors in the common stock of publicly held enterprises do not expect that some members of the class will receive more dividends or larger distributions on liquidation than others. Investors' expectations of equal treatment legitimately derive from the language of the investment contract, which imphes, if it does not expressly state, that if dividends or hquidating distributions are paid, they will be paid equally to all. ${ }^{36}$ Furthermore, such expectations are the common understanding of the investment community. Neither finance texts nor other relevant literature suggest any other order of affairs. On the contrary, they plainly conteniplate equahty of treatment. ${ }^{37}$ There do not appear to be any corporate char-

34. It has been suggested that corporate stock owned by high income investors appreciates in value substantially faster than stock owned by investors with lower incones. M. FELDSTEIN \& $S$.

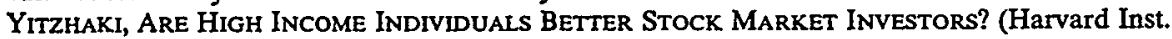
of Econ. Research Discussion Paper No. 918, Sept. 1982). To the extent that frozen out public investors are likely to have lower incomes and assets than controlling stockholders, a rule of unequal treatınent also has the effect of redistributing assets systematically from the less affluent to the more affluent.

35. See, e.g., J. RAWLS, A THEORY OF JUSTICE $\$ \$ 13,46$ (1971).

36. See supra note 12 .

37. Indeed, the standard valuation models in finance textbooks necessarily assume homogeneous treatment of shares of stock of a given class in making distributions. See, e.g., J. WESTON \& 
ters of publicly held enterprises which expressly provide for discretionary disparate treatment of shareholders of the same class. The contrast between the absence of such provisions and the presence of exphicit offers to stockholders of the option to accept individual variations in particular dividends, ${ }^{38}$ or different classes of stock carrying different dividend privileges, supports the impression that the normal mvestor expects equal treatment.

The failure of prospectuses or other hiterature attencling the issuance of corporate stock to negate the possiblity of disparate treatment does not derive froin any perceived belief that it is necessary to do so in order to allay prevalent investor fears that homogeneous treatment is not their entitlement. On the contrary, if such treatment were not seen to be both their expectation and their entitlement, there is no cloubt that the SEC would require selling literature explicitly to spell out any potential for unequal sharmg. ${ }^{39}$

It is, of course, possible for a society to provicle an investment regime in which unequal treatment is the expectation unless the investor expressly contracts for equahty. But expectations of unequal treatment are not the prevalent concepts among investors in our financial cominunity. Efforts to change these prevailing notions would take time and would be very costly, if indeed they would even be effective. Moreover, they would result in less efficient arrangements. If investors generally assume that they will be equally treated, the least costly allocation of risks and returns leaves it to the promoters or organizimg majority to

E. Brigham, Managerial Finance ch. 17 (7th ed. 1981); J. Cohen \& E. Zinbarg, 1NVestMent Analysis and Portfolio Managerant ch. 5 (1977); W. Lewellen, The Cost of Capital 8893 (1969). And some are more explicit. See N. BuChanan, supra note 15, at 84. See also L. Gower, The Principles of Modern Company Law 349-50 (3d ed. 1969); id. at 403-05 (4th ed. 1979).

38. Distributions expressly payable either in stock or in property at the election of the shareholders are contemplated by I.R.C. $\$ 305(b)(1)$ (1954). See Rinker v. United States, 297 F. Supp. 370 (S.D. Fla. 1968); Fisher v. Commissioner, 62 T.C. 73 (1974). See generally B. BITTKER \& J. EUSTICE, FEDERAL INCOME TAXATION OF CORPORATIONS AND SHAREHOLDERS $\$ \$ 7.61-.62$ (4th ed. 1979).

39. If a rule of unequal sharing were permitted, exphicit admonition of potential inequality should be required in any such disclosures to investors. There is reason to believe that people tend to underestimate the probability and consequences of events that are difficult to imagine or beyond the realm of normal experience, including failure of complex systeins; they also tend to have illusions of control, with resulting overly optimistic estimates of outcoines that are a natter of ehance or luck. See Tversky \& Kahneunan, Judgment Under Uncertainty: Heuristics and Biases, 185 SCIENCE 1124 (1974); Tversky \& Kahneinan, Prospect Theory: An Analysis of Decision Under Risk, 47 Econometrics 263 (1973); I. Janis \& L. ManN, Decision Making 14-17 (1977); G. Katona, Psychological Economics cli. 14 (1975); G. CAlabresi, The Costs of Accidents 55-57 (1970); Zeckhauser, Procedures for Valuing Lives, 23 PUB. PoL'y 419, 437-38 (1975). The contingency of disparate distribution on dissolution or going private or of unequal treatinent in a merger or liquidation is likely to be among such renote future events which are obscured by overoptimisn when one buys securities. $C \mathcal{C}$. Arrow, supra note 27, at 1-8. 
contract out of such treatment if they so desire. They are better able than the public investors to anticipate any legitimate needs for non-pro rata distributions to themselves and to specify them. And providing exceptions to a general rule of equality is simple and less costly than specifymg the exceptions to a general rule of inequality. ${ }^{40}$

Accordingly, corporation law and fiduciary principle provide a standardized contract which removes the element of uncertainty by presuming homogenized treatment of mvestors of the same class in the distribution of dividends and on liquidation. Unequal treatment would be justified only if expressly provided for in the investment contract. ${ }^{41}$ In the absence of sucli a provision, majorities are not, and should not be, permitted to make disparate distributions to themselves on dissolution. ${ }^{42}$

40. See supra note 15.

41. In theory, minority consent could be inferred from express waiver of equality of distribution at the time of dissolution, upon full disclosure of the magnitude of the disproportionate distribution. That solution would be feasible if the minority consisted of a single person (although it would give him "holdup" powers). But when, as is the case in publicly held companies, the minority consists of dispersed investors, whipsaw possibilities obstruct volition. And im any event, the volitional character of consent solicited through the proxy machinery is, if not fictional, not comparable to the consent of a single owner of all the ininority stock or even the consent of a majority in a context where no controller exists. See Brudney \& Chirelstein, Fair Shares in Corporate Mergers and Takeovers, 88 HARv. L. Rev. 297, 340 n.89 (1974); Brudney \& Chirelstein, $A$ Restatement of Corporate Freezeouts, 87 Y ALE L.J. 1354, 1359 (1978) [hereinafter cited as Brudney \& Chirelstein, Corporate Freezeouts]; Weiss, The Law of Take-Out Mergers: A Historical Perspective, 56 N.Y.U. L. Rev. 624, 676-77 (1981); Manning, Book Review, 67 Yale L.J. 1477, 1485-87 (1958) (reviewing J. Livingston, THE AMERICAN STOCKHOLDER (1958)).

42. It does not detract from this couclusion that stockholders subject themselves to managerial and majority rule about the conduct of the affairs of the enterprise. The premise of all "for profit" enterprise is that those who conduct its affairs will seek to maximize the wealth of its stockholders. For "the initial position" of the investors, therefore, to contemplate that management, and indeed the majority of the stockholders, may make decisions with respect to the profitseeking use of corporate assets which a minority opposes implies consent, ex ante, to corporate action designed to increase the value of the enterprise. It does not imply consent to unajority decisions having to do with disparate distribution of the assets anıong the inembers of the classat least if no equivalent compensating increase in the values being distributed to eacls results from permitting the disparate dividend.

Nor is a rule of equal treatment in distributions and reorganizations mcompatible with the evolution of Ainerican corporation law that has resulted in eliminating each shareholder's veto on fundamental changes in corporate structure or purpose, and has permitted, within limits, the forced cashing out of his common sliares. See generally Manning, The Shareholder's Appraisal Remedy: An Essay for Frank Coker, 72 Y ALE L.J. 223, 246 n.38 (1962); Weiss, supra note 41 at 62641; Camey, Fundamental Corporate Changes, Minority Shareholders, and Business Purposes, 1980 Am. B. Found. ResEarch J. 69, 77-97; Greene, Corporate Freeze-out Mergers: A Proposed Analysis, 28 STAN. L. REv. 487, 487 n.3 (1976). The effect of this evolution has been to create flexibility for the expansive inanagement of aggregations of capital. To eliminate a veto in order to facilitate added risk-taking by a majority or by management in pursuit of larger profit for the common venture neither requires nor suggests open ended permission to alter the terms of sharing among stockholders for the benefit of controlling shareholders and at the expense of others. 


\section{b. Implementing the Requirement of Equal Treatment}

In the absence of a rule of formal identity of treatment, the uncertamties as to the values being distributed suggest that enforcing a rule of substantively equal treatment would present costs and difficulties that would assure soine inequality of result. ${ }^{43}$ While it is for the inost part academic, the question whether a requirement of formal identity of treatment would be too costly raises several relevant issues. It also has implications for the "going private" problein. If the business is worth more as a going concern than disassembled and sold, it is plainly preferable to keep the business intact. To effect that result while preservimg equality of participation requires either: (1) precluding dissolution and letting the controller continue the venture; or (2) permitting dissolution and either forcing a sale to a stranger or permitting the controller to buy it for cash at a higher price than strangers bid.

The best assurance of equality of distribution on dissolution, at least where the controller is not a publicly lield parent corporation, is to sell the enterprise for casl and distribute the proceeds. To do that requires sale to, or solicitation of bids by, strangers. ${ }^{44}$ Anything other than a sale of the business to a stranger or at a sale price above that which a stranger would pay is likely (because of valuation ambiguities and costs of policing) to constitute an appropriation by the controller of a disproportionate share of the value of the enterprise. To force him to find a buyer may impose a cost ${ }^{45}$ - unless the common per share interest of the controller and the other imvestors in the best sale price results in the controller pressimg to find the highest price available.

If the controller is able to put the assets to more profitable use than

43. See supra note 30 .

44. To suggest that the controller be "forced" to sell to a stranger is to suggest an analogue to the power of a partner or in some jurisdictions a minority shareholder in a close corporation, see, e.g., Gabhart v. Gabhart, 267 Ind. 370, 370 N.E.2d 345 (1977), to compel sale of the enterprise in a judicial proceeding, MINN. STAT. ANN. §302A.751(a) (West 1983). See also Hetherington \& Dooley, Illiquidity and Exploitation: A Proposed Statutory Solution to the Remaining Close Corpo. ration Problem, 63 VA. L. REv. 1 (1977). Fornally, the minority stockholder in a public corporation has no such power. But a rule of equal treatment will give him coinparable leverage. To be sure, a bargained "settlement" between controllers and outsiders is less feasible in the case of a public corporation than in the case of a private firm. But the limited ability of a dispersed unimority to bargain-either effectively or responsibly-is a cost of being public which is not self-evidently to be borne fully by the minority, even in the interest of a theoretical social gain. $C f$. infra text accompanying note 148 .

45. The administrative cost of finding a best user is no impediment to the controller's search for a best use. It is allocable to the busmess. If the controller does the searching and incurs speeial costs he can be coinpensated as would any other agent for finding a buyer. But apart froin sucl identifiable coinpensation for work done, to allow the controller to take more than his proportionate share for consenting to sell the entire business (not unerely control) is not rationally necessary to induce him to permit or imitiate the sale, any inore than allowing him to steal from the coinpany is rationally necessary in order to induce his consent. 
strangers can, the minority is no worse off, and society is better off, if the controller is allowed to purchase the business at a higher price than a stranger offers. Whether a regime that permits him to do so will inhibit his efforts to find a buyer or will chill strangers' bids is probleinatic. Those effects are neither implausible nor unknown. ${ }^{46}$ They suggest that requiring a sale to a stranger and severing the controller's connection with the business nnay well be preferable to allowing an auction in which the controller can bid.

It does not preclude that conclusion that requiring a third-party sale may induce the controller to retain control of a business without dissolving it, and permit him to make continuous improper diversion of increased profits to himself. To be sure, a nice question is raised as to whether it is desirable to prevent improper diversion by the controller on hquidation, if to effect that prevention he is encouraged to continue diverting assets to himself in drips and drabs on a continuing basis. It has been noted that the fiduciary rules governing manageinent's or the controlling stockholders' daily conduct of corporate affairs permit shppage which allows greater diversions fronl stockholders than any level of acceptable agency costs should rationally allow. ${ }^{47}$ That condition requires attention, and more faithful judicial enforcenent of the proclaimed fiduciary rules. ${ }^{48}$ But it does not justify allowing controllers to exploit the loose operation of fiduciary rules by appropriating in one transaction the capitalized value of the perquisites they nay be able to extract improperly over time. ${ }^{49}$

\section{Going Private}

Going private; whether effected through an issuer's tender offer, by a leveraged buyout, or simply by merger with a duminy corporation,

46. See, e.g., SEC, REPORT ON THE STUDY AND INVESTIGATION OF THE WORK, ACTIVITIES, Personnel, and Functions of Protective and Reorganization Committees pt. VIII at 17 19 (1940).

47. See, e.g., Anderson, supra note 1, at 744-48, 757-61.

48. It has been suggested that the markets set appropriate limits on the "slippage" permitting agents to divert assets from shareholders. See Jensen \& Meckling, supra note-1; Fama, supra note 1; Winter, State Law, Shareholder Protection and the Theory of the Corporation, 6 J. LEGAL STUD. 251 (1977). Whether society would be better off if all slack were eliminated from agency costs by rules which both tighten restrictions and greatly reduce the need to monitor has been debated at length. See, e.g., Anderson, supra note 1, at 777-93; Cary, Federalism and Corporate Law: Reflections Upon Delaware, 83 Y ALE L.J. 663 (1974). That there is some room for improvement, however, is not often denied.

49. Nor does it follow from the risk of such behavior that a rational mvestor should choose a rule which allows him to receive a premium over market price from the controller and enables him to "get ont" with cash. He might rationally conclude that generally the likelihood under that rule of his being forced out at a price lower than imminently realizable value is great enough to make a rule of equal treatinent preferable even if in some cases he will lose a premium or run the risk of the controller's efforts to divert assets on a continumg basis. See infra note 67. 
is a process for eliminating public stockholders by acquiring their stock for a price (generally in cash) that is somewhat higher than the prevailing market price. On the assumption that such transactions are unilateral and coercive - actually coercive to the extent they are inergers; and effectively coercive in the case of initial buy backs by tender offers which threaten the inarket liquidity of the public's shares-they are likely to force precisely the saine inequality as would a disparate distribution on dissolution. The controller keeps the "real" assets and the minority receives cash. Is there any reason to dilute the principle of equality, either in substance or in forn for such transactions? If the principle of equality requires, so far as possible, formal identity of treatment among shares in liquidating distributions, should it preclude going private transactions?

The arguments for going private focus on the "savings" which the process effects. The essential contention is that by reducing costs, going private increases the profitability and therefore the value of the corporation. ${ }^{50}$ Few of the cominentators on going private, ${ }^{51}$ and none of the courts dealing with the problein, however, urge realization of those gains by a rule of substantive inequality-i.e., that the cashed out public should receive less per share than the controlling stockholders, whether the difference is a function of hidden values not reflected in the price of the corporation's stock or of cost savings or otherwise. Since going private is simply an alternative process for effecting the equivalent of distributions in dissolution, all the reasons for beheving that a rule permitting disparate treatınent on liquidation is both too costly and inequitable argue against invoking such a rule for going private.

If substantively equal treatment is the appropriate rule, the questions remain whether it can be achieved without categorically forbidding goimg private, and if not, whether the cost of thus effecting formally equal treatınent is worth the benefit. The arguinent for a categorical rule rests primcipally on the difficulty, if not impossibility, of enforcing a rule of substantively equal treatment if each case must be litigated to determine whether unrevealed values in the firm exist and are properly taken into account in the price offered. ${ }^{52}$

The voluminous literature on going private alludes to soine dubi-

50. See Wolfson, supra note 9, at 978-80; Easterbrook \& Fischel, supra note 8, at 729-30; Solomon, Going Private, 25 Buffalo L. Rev. 141, 143 (1975); Note, Going Private, 84 Yale L.J. 903, 907 (1975); Borden, supra note 17, at 1006-13. But see Brudney \& Chirelstein, Corporate Freezeouts, supra note 41, at 1366-67.

51. But see, e.g., Easterbrook \& Fischel, supra note 8, at 728-31.

52. See Brudney, supra note 27; Brudney, $A$ Note on "Going Private," 61 VA. L. Rev. 1019, 1023-25 (1975) [hereinafter cited as Brudney, Going Private]; Brudney \& Chirelstein, supra note 41. Cf. Securities Exchange Act Release No. 15,572, [Current] FED. SEC. L. REP. (CCH) \ 24,115 (Feb. 15, 1979). 
ous costs of a categorical prohibition, ${ }^{53}$ but the more serious claims are that such a prohibition: (a) would prevent elimination of the agency costs and the expenses of being public, such as compliance with the federal securities laws, and the other apparatus that aids imvestors im momitoring management; and (b) would cause public investors to lose premiums above the inarket price of their stock which they might be paid in the contrived merger or repurchase. ${ }^{54}$

(a)

The savings derived from being private instead of public are hard to determine, and even harder to evaluate agamst the costs of going private. The elimination of law compliance expenses is apt to be more than trivial as a percentage of total costs in the case of sinaller companies; but it becomes less significant as the size of the company $m$ creases. ${ }^{55}$ On the other hand, the costs of acquiring those savings by going private, although only a one-shot expense, are not irrelevant. ${ }^{56}$ The claimed savings im agency costs when controllers become $100 \%$ owners nuay be theoretically real, ${ }^{57}$ but they are of uncertain practical import. ${ }^{58}$ To a large extent they are apt to constitute little more than a redistribution of returns. 59

The claimed ganıs fronı permitting going private inust be weighed

53. The notion that distributing corporate cash by repurchase of stock is a socially useful transfer of cash from a less desirable to a more desirable use, see Petty \& Pinkerton, The Stock Repurchase Decision: A Market Perspective, 1 J. AccT. Auditing \& FIN. 99 (1978), has been urged as support for going private transactions, Hetherington, supra note 9, at 239. A corporate repurchase program not designed to "go private" may possibly refiect a lack of profitable use by the repurchasing firm for the funds. But that lack of profitable use is not congruent with the assumptions about the contemplated development of the firm that goes private-particularly when it is effected with borrowed funds. See Brudney, Going Private, supra note 52, at 1046 n.89 (1975).

Whatever may be the costs theoretically imposed on publicly held firms by disclosure requireunents, there is hittle or no basis to behieve that the costs are of practical significance. Indeed, if losing the competitive advantage of some new development is a significant disclosure cost to the firm, news of that development is presumably of particular imterest to the frozen out investor, who should either be given the information or not be frozen out.

54. See Borden, supra note 17, at 1015; Hetherington, supra note 9, at 243, 247.

55. Cf. Borden, supra note 17, at 1002-03 (arguing that for sunall issuers, a per se prohibition of goimg private transactions would work a lardship on the issuer without any corresponding public gain); See S. Phillips \& J. Zecher, The SEC AND The Public Interest 49 (1979).

56. See Brudney, Going Private, supra note 52, at 1033.

57. See Wolfson, supra note 9, at 979. But, if the initial going public correctly reflected agency costs, as Jensen and Meckling suggest, see supra note 1, in a rational world it can only have occurred if there was a larger social gam to going public. Unless circumstances can be shown to have changed inaterially by the time of going private, the act of doing so will lose that net gaim.

58. Cf. supra text accompanying note 25 .

59. The added perquisites and tax avoidance that insiders gaim from going private are not gains to the corporation or to society. The fact that the company has not been as successful as expected when it went public and therefore that its stock is not as useful for corporate purposes (e.g., compensation options or acquisition currency) as initially conteinplated does not make goimg 
against the costs. Going private entails losing the benefits of being public, including the benefits of diversifying the risks of the enterprise by having public investors, and by increasing investors' opportunities to diversify by having inore investunent vehicles. Moreover, to the extent that the risks attending a rule permitting going private are adequately disclosed, ${ }^{60}$ fears and uncertainties will be generated annong potential initial investors about unfairness to them in subsequent going private transactions. Hence, to permit going private without assuring equal treatinent, in sharing both the savings and the value of the expected increase in earnings, ${ }^{61}$ will raise the cost of going public. ${ }^{62}$

In short, the recital of dollars and intangible values saved by going private does not justify the conclusion that permitting such transactions offers a social gain unless the costs, tangible and intangible, are also weighed. No such weighing has been, or is likely to be, done in empirical studies. But the considerations supporting a rule of equal treatinent in the liquidation context suggest that significant costs will attend any rule which permits controllers to yield to their natural desire to take all—and more than all - of the benefits froin going private, (including

private a value increasing event. The nonpublic stock is no better for such corporate purposes than the depressed public stock.

Elimination of the cost of policing self-dealing may be a significant social saving if the controller is a parent corporation which transacts regular business with its subsidiary. But it is less likely to reduce costs if the controllers arc private individuals. See Eisenberg, The Legal Roles of Shareholders and Management in Modern Corporate Decisionmaking, 57 CALIF. L. REV. 1, 132 (1969).

60. The misuse of inside information in going private transactions is most likely to occur in the case of the sinaller companies for which going private is most feasible. While inside inforination exists for most coinpanies, the sinaller ones (for which the cost of being publie is proportionately largest) are the firms for which the concealed information is likely to be the most significant, becausc the market for stocks of those firms is least likely to impound the inside information in their price. And efforts by outsiders to bitigate the "value" questions are fraught with costly impediments. See supra note 30.

61. The notion that the insider could mistakenly appraise the unrevealed information too favorably and therefore mistakenly cause corporate purchase of the stock at too high a price is not demonstrated by studies showing that corporate repurchase programs are often followed by market prices lower than the repurchase price. See Hetherington, supra note 9, at 236 n.169; studies cited supra note 28 . The reasons impelling repurchase (in contrast to going private) prograins include raising or stabilizing the price of stock at a level which management believes desirable. The fact that the market still believes the stock is worth less than management's repurchase price after the repurchase progran terminates suggests that management's valuation was indecd faulty and that the inarket's prior estimate was correct. But in going private programs the tilt is not quite the sanie. If the repurchase will favor the direct pecuniary interest of the repurchascr, as is contemplated in the case of going private, there is good reason to believe that the imside information will be more accurately perceived by the purchaser than by the inarket. And the information nced not be-and is not likely to be-of the kind that either law or private effort will flush out so as to affect the market price at the time of purchase. Hence reliance on disclosure requireinents to protect stockholders is least valid in sucli cases.

62. As noted, supra text accompanying notes $31 \& 32$, the risk of being frozen out cannot be diversified away. 
unrevealed enterprise values) are apt to be significant. Certainly they are sufficient to cast substantial doubt upon the magnitude of the net social gains, if any, froin going private, or from a rule which permits going private but imposes the costs of litigating to determine whether equal treatinent has been accorded. ${ }^{63}$

(b)

The suggestion that a rule of equahty will preclude individual imvestors from receiving more than the market price for their shares has merit only if the inarket correctly prices their stock (i.e., reflects all relevant information) when the firm goes private; or if there is no other mode of allocating to each imvestor the "real" value of his shares in that enterprise (including expected improvennent). But neither condition is likely to be true.

To the extent that inarket prices do not correctly reflect the value of stocks of firms which insiders seek to take private, public imvestors are likely to benefit by a rule forbidding going private. There is good reason to believe that controlling stockholders (whose interest in doing so is more pointed than disinterested managers') will take the company private when the market errs in their favor because it does not yet have their inside information about the firm's improving prospects. ${ }^{64}$ While systenatic empirical evidence of this practice is not available, ${ }^{65}$ and in any particular case insiders may be wrong, it would certainly be con-

63. Even if going private saves agency and disclosure costs by eliminating the need for then, see Lowenstein, supra note 27, the question still reinains whether the controller should be einpowered unilaterally to determine when those costs should be saved and whether or how the savings should be shared. It is no answer to this faimess problem simply to assert, as though extrinsic fate or even a third person offering an arm's-length price and expecting to profit from acquiring and improving the venture were determinants of the price paid to the public, $c f$. infra note 64 , that costs are being saved for society. It is particularly an inadequate answer when contrasted with the possibility that comparable savings for society may be made by selling the entire venture to a third party. The price paid by a third party may well bring more to the minority investor without hitigation than the going private price offered by the controllers, even after litigation to "correct" it. See supra note 44.

64. See, e.g. , Berkowitz v. Power/Mate Corp., 135 N.J. Super. 36, 342 A.2d 566 (1975); In re Talley Indus., Investınent Company Act Release No. 5953, [1969-1970 Transfer Binder] FED. SEc. L. REP. (CCH) \77,774, at 83,792 (Jan. 9, 1970). See also supra note 29. The notion that management can disclose inforınation which outside bidders cannot disclose, see, e.g., Hetherington, supra note 9, at 235, does not mean that manageinent will disclose it-although recent SEC efforts increase the probability of its doing so, see SEC Rule 13e-3, 17 C.F.R. $\$ \$ 240.13 e-3,240.13 e-100$ (1981). Hetherington states that "[t]here is a fair and adequate price which represents the investment value" of an investor's shares, and that the investor should be allowed to receive that price even at the cost of expulsion from the venture. Hetherington, supra note 9, at 249. But if somewhere in the sky there exists a fair price, that price is not mevitably offered in the inarket during a going private operation. On the contrary, at that time the market is likely to be skewed systematically to the disadvantage of the public investor. If equality is the test, the fair price is not likely to be paid in that enarket.

65. But see supra note 29. 
trary to their economic interests to refrain from attempting to achieve and retain such gams. And the temptation to yield to self-interest would be enhanced by market imperfections for (and the mampulability of prices of) stocks of precisely those companies that are small enough to go private.

While going private thus is likely to deprive outsiders of thcir equal share of the firm's enhanced value, arguably it gives them more than they would get if a rule of equality precluded insiders from going private. But the fact that a rule of equal treatment would thus precludc payments of premiums to public investors for their stock need not preclude them from receiving their aliquot share of the firm's true value, at least to the extent reflected in the proffered premium. ${ }^{66}$ If the controller is prevented from going private im such circumstances, the venture will continue public and the minority holders will share im the not remote future gains whose potential is not yet reflected in its market price. $^{67}$ If controllers do not wish to contimue with the minority as their

66. The suggestion that a prohibition on going private reflects a view that "the interest of shareholders in receiving more money [for their stock] is irrelevant," Easterbrook \& Fischel, supra note 8 , at 730 , is no more accurate than would be the attribution of a similar view to those who would prevent management from seeking competing bids in takeover contests. See Easterbrook \& Fischel, The Proper Role of a Target's Management in Responding to a Tender Offer, 94 HARv. L. REv. 1161, 1164 (1981). The notion that a rule thus designed to protect stockholders impedes their "free choice" to sell to the corporation at a price they choose assumes that they have "free choice." Cf. Hetherington, supra note 9, at 241, 242 n.183 (arguing that, as a general principle, sharcholders benefit from rules that offer them a chance to receive premiums for their shares). But if the market is skewed, their choice is not quite so "free," particularly if they are under pressure to sell in a going private atunosphere. In that context, the premium offered to investors is somewhat illusory. It is an economic increment only if the market price is not skewed or the "real" value of the stock is not otherwise available to investors. Real value is more likely to be available to them under a rule which discourages controllers' efforts to depress the inarket and cncourages controllers more quickly to reveal favorable information (because they are precluded from using it for their own trading benefit). Investors could rationally prefer a rule under which sometimes they would not gain (because a premium over unarket cannot be paid) but more often they would gain in possibly larger amounts (because they will not be deprived of values not reflected in stock prices).

It is not, as Hetherington suggests, the power of a majority to exclude a minority that is at issue. See id. at 246 . It is the lack of minority power to bargain over the terns of exclusion. If a dispersed minority of public investors does not have the power of a minority partner (or occasionally of a minority shareholder in a close corporation) to bridle the majority's grced by threat of liquidation to be enforced in court, some other remedy is needed. A flat prohibition against going private implicates such a remedy-sale by the controller of the enterprise to a stranger. To push the analogy further toward that of a close corporation by allowing courts to determine the equality of price is to perpetuate the dispersed minority's disadvantage; the minority's power to hitigate to a fair conclusion is as inuch less than a partner's as their bargaining power if they cannot force hiquidation.

67. The controller's decision to remaim public is not as dangerous to public investors as has been suggested. Hetherington, supra note 9, at 248-49. The enterprise, although controlled by a single power, is not wholly private. A market exists for its stock and a prohibition against going private will prevent forccd contraction of that market. The insiders' ability to keep the market depressed attenuates as time goes on. Hence if there is an unrevealed potential at the time of 
partners, they can sell the enterprise to third persons. It is not unreasonable to suppose that noncontrollers are likely to benefit more from such sales than from allowing the controller to determine what price he will pay to eliminate them. ${ }^{68}$

Neither the state statutes nor the cases deal effectively with the problem of going private. Judicial imterpretation of the merger statutes has rarely precluded majorities from eliminatimg public imvestors by merger with a dummy corporation. ${ }^{69}$ While a few courts have suggested that fiduciary considerations forbid, or at least limit, the exercise of such power, the answers they have given are not entirely clear. ${ }^{70}$ The cases all appear to assume that all stockholders should receive equivalent values per share in the "breakup" of the old corporation. But the next step to assure such equivalence-insistence upon identical distributions, or a categorical prohibition against going private-is not easily taken. Courts are apparently fearful that sucli a step will preclude going private transactions which increase the value of the corporation or the wealth of mdividual stockholders. On the other liand, they appear to be apprehensive that implementing the equality princi-

going private, it is likely to be recognized in the market over time. While the possibility remains that controllers will make continuous improper diversions of assets over time, that cost is no greater by reason of a rule prohibiting going private than it would be without such a rule. There is reason to strengthen the rules against such diversion rather than to permit it to occur more effectively by means of a single going private transaction.

68. See supra text accounpanying note 44 .

69. See Bryan v. Brock \& Blevins Co., 490 F.2d 563 (5th Cir.), cert. denied, 419 U.S. 844 (1974); Berkowitz v. Power/Mate Corp., 135 N.J. Super. 36, 342 A.2d 566 (1975). State merger statutes appear to permit the formally disparate distribution contemplated in going private and parent-subsidiary cash-out mergers. Long-form statutes, as well as short-form statutes, contemplate payment by merging corporations of cash or redeemable securities to all stockholders of the merging partner. See, e.g., MODEL Business CORP. ACr $\$ \S 71,75$ (1979). It may plausibly be argued that permission to pay anything other than common stock of a corporation in a merger was given in long-form merger statutes solely to facilitate arm's-length mergers, and should not be applicable to parent-subsidiary mergers or to going private mergers. Bryan v. Brock \& Blevins Co., 490 F.2d 563 (5th Cir. 1974), cert. denied, 419 U.S. 844 (1974). Weiss, supra note 41, at 63233. Although that contention is at odds with the short-form merger legislation and the two-step acquisition by tender offer and inerger, $c f$. id. at 641 ; Krafcisin v. LaSalle Madison Hotel Co., [1972-1973 Transfer Binder] FED. SEC. L. REP. (CCH) I 93,586 (N.D. Ill. June 19, 1972) (minority shareholders have no right to continued participation in the enterprise and may be cashed out in a tender offer prior to a reorganization), it need not preclude a requirement of "all common stock" mergers for absorptions of subsidiaries by long term parents owning up to $90 \%$ of a subsidiary's stock. $C f$. CAL. CORP. CODE $\$ 1101($ e) (West Supp. 1983) (holders of shares of the same class of stock of any constituent corporation in a merger must be treated equally in distributions of cash, property, rights or seeurities).

70. See Bryan v. Brock \& Blevins Co., 490 F.2d 563 (5th Cir.), eert. denied, 419 U.S. 844 (1974); Berkowitz v. Power/Mate Co., 135 N.J. Super. 36, 342 A.2d 566 (1975); Jutkowitz v. Bourns, No. C.A. 000268 (Cal. Super. Ct. Nov. 19, 1975); Kaufmann v. Lawrence, 386 F. Supp. 12 (S.D.N.Y. 1974), affd per curiam, 514 F.2d 283 (2d Cir. 1975); Outwater v. Public Serv. Corp., 103 N.J. Eq. 461, 143 A. 729 (Ch. 1928), aff'd per curiam, 104 N.J. Eq. 490, 146 A. 916 (1929). 
ple by a "fairness" standard would be difficult to administer." Hence they fret and discourage, but do not forbid, "going private" transactions. ${ }^{72}$

Similar tensions have afflicted the SEC's treatment of going private transactions. While at one time it stated, although not without sharp opposition froin the organized securities bar, that it had the power to require a going private transaction to be "fair,"73 it has not imposed that requirement. Instead, it has receded to the position of requiring disclosure of relevant information including reasons for considering the transaction to be fair. ${ }^{74}$

If a categorical prohibition is too costly, a rule of equal treatınent inay be implemnentcd, albeit less effectively and not without cost, by judicial or administrative appointınent of negotiators ${ }^{75}$ to act for the minority in going private, or by requiring prior approval of the transaction by an administrative agency or the courts. But if the priniciple of substantive equahity is appropriate, nothing short of such requirements would make it effective.

\section{Parent-Subsidiary Mergers}

Is there any reason to perinit a publicly held parent corporation to

71. In addition to the difficulty of adducing relevant data and determining permissible inferences of value, see Brudney, supra note 27, there may be problems of determining standards of fairness. Equality of treatment is not the theme of all conceptions of fairness in assessing the propricty of the price paid to investors in going private freczeouts, at least when the freezeout is the second step in a takeover. See, e.g., Chazen, Faimess from a Financial Point of View in Acquisttions of Public Companies: Is "Third Party Sale Value" the Appropriate Standard?, 36 Bus. LAw. 1439 (1981).

72. There is no more reason to tolerate disparate treatment of minority stockholders in cases where corporations go public in a coerced reorganization than to do so where corporations go private. Judicial uncertainty about prescribing a categorical prohibition in such cases is suggested im Jones v. H.F. Ahmanson \& Co., 1 Cal. 3d 93, 460 P.2d 464, 81 Cal. Rptr. 592 (1969). The result in that case may be explained by the court's uncertainty as to the significance of contributions of additional assets by the controllers to, and therefore assumption of added risks in, the reorganized enterprise by which going public was effected.

73. Securities Exchange Act Release No. 14,185, [1977-1978 Transfer Binder] FED. SEC. L. REP. (CCH) I 81,366 (Nov. 17, 1977).

74. SEC Rulc 13c-3, 17 C.F.R. $\S \S$ 140.13e-3, 240.13e-100; Securities Exchange Act Release No. 16,075, [1979 Transfer Binder] FED. Sec. L. REP. (CCH) I 82,166 (Aug. 2, 1979); $c$. Securities Exchange Act Release No. 15,572, [Current] Fed. SEC. L. Rep. (CCH) I 24,115 (Feb. 15, 1979).

75. See, e.g, In re Woods Corp., Securities Exchange Act Release No. 15,337, 16 SEC DOCKET 166 (1978) (consent case); In re Spartek, Inc., Securities Exchange Act Release No. 15,567, [1979 Transfer Binder] Fed. SEC. L. Rep. (CCH) I 81,961 (Feb. 14, 1979) (same); SEC v. Beisinger Indus. Corp., 552 F.2d 15 (1st Cir. 1977), affg 421 F. Supp. 691 (D. Mass. 1976) (contested case involving appoimtment of agents to effect compliance with law in the future); SEC $v$. Koenig, 469 F.2d 198 (2d Cir. 1972) (same); SEC v. Western Geothermal \& Power Corp., [1979 Transfer Binder] Fed. SEC. L. ReP. (CCH) I 96,920 (D. Ariz. May 23, 1979) (same), See also SEC v. Data Access Sys., [1982 Transfer Binder] FED. SEC. L. REP. (CCH) ๆ 98,779 (D.N.J. Aug. 17, 1982); Chazen, supra note 71, at 1467. Cf. Principles of CORPORATE GOVERNENCE AND StruCTURE: RESTATEMENT AND RECOMMENDATIONS \& 703() (Tent. Draft No. 1, 1982) (ALI proposal for settlement of derivative suits by court appointment of special panel). 
make unequal distributions to its subsidiary's stockholders upon dissolving or inerging its subsidiary? ${ }^{76}$

\section{Entitlement to Equal Distribution}

The claim that minority stockholders should be willing to accept anything more than the market price for their stock no more supports a rule of disparate treatment in the case of a parent-subsidiary inerger than in liquidation or goimg private transactions. The integrity of that market price as a reflection of value is not unsullied. The parent can, and there is reason to believe it does, affect the market price of the subsidiary's stock in anticipation of a merger. ${ }^{77}$ The parent thus can take advantage of the minority because that price does not then reflect fair value. Hence market price is not likely to be an adequate subtrahend in calculating stockholder gain. Any rational stockholder faced with such a prospect ex ante will see little or no likelihood of personal gain, and rightly fear losses froin such mergers. One result of a rule allowing such disparate treatment, therefore, will be to increase the cost of capital. ${ }^{78}$

To be sure, a minority investor in the subsidiary of a publicly held parent may, to a limited extent, be able to diversify the risk of being inulcted in a subsidiary by acquiring the potential for being rewarded in a parent. ${ }^{79}$ The actual distribution of stockholdings, as well as a certain amount of observed investor "irrationality," ${ }^{\circ 0}$ suggests that even in a perfect market many investors are not-and are not likely ever to be ${ }^{81}$ - sufficiently diversified to avoid undue unsystematic economic risk.

76. State merger statutes appear to permit such formally disparate distributions. See Alcott v. Hyman, 208 A.2d 501, 508 (Del. 1965); Abelow v. Midstates Oil Corp., 189 A.2d 675 (Del. 1963); See Cal. CoRP. Code $\$ 1001$ (West 1977 \& Supp. 1983). But they do not suggest that substantive disparity is permissible.

77. See supra note 29; TSC Indus. v. Northway, Inc., 426 U.S. 438 (1976); Atchley v. Qonaar Corp., [Current] FED. SEC. L. ReP. (CCH) I 99,155 (7th Cir. Apr. 1, 1983). See also M. Jensen \& R. Ruback, The Market for Corporate Control: The Scientific Evidence 27 (Apr. 1983) (unpublished manuscript forthcoming in volume 11 of the Joumal of Financial Economics). And in any event, the value of $100 \%$ ownership may be greater per share than market price. See Lowenstein, supra note 27.

78. A system which permits such diversion by controllers entails further costs. See text accompanying notes 31-33.

79. See Easterbrook \& Fischel, supro note 8, at 711-14.

80. See Arrow, supra note 27; Kahn, supra note 27, at 24.

81. If, as the New York Stock Exchange reports, New York STOcK Exchange, SHareHOLDER OWNERSHIP 1981, at 2, 26-27, more than 60\% of the approximately 30 million adult individual stock investors own stock having a value of less than $\$ 10,000$ (48\% with a value of less than $\$ 5,000$ ), a fairly large portion of individual investors is not likely to be adequately diversifed. The report indicates that five percent of those investors have invested exclusively in equity mutual funds and about $10 \%$ more have some equity mutual fund stocks in their holdings. Unless such investors imvest only in appropriate inutual funds they will not be adequately diversified. 
However that inay be, the argument that investors in a subsidiary of a publicly held parent may diversify away the risk of being mulcted faces some a priori obstacles. It is not that the mvestor must seek to own stock in the parent of the subsidiary in which he mvests. It is that the investor's range of choices of potential parents is skewed agamst him. Privately owned parents are unavailable; and there are fewer public parents than nonparents, and fewer potential parents than potential subsidiaries. ${ }^{82}$ Moreover, the investor can not be certam that parents in which he invests will not become subsidiaries, otherwise cease to be parents, or cease to be publicly lield parents. And finally, investors inust exercise some degree of selectivity among parents in order to find enterprises which combine appropriate economic risk-return characteristics with the right inuleting potential. ${ }^{83}$

The cost and limited effectiveness of the search for an appropriate parent affect, if they do not eliminate, the investor's ability to diversify adequately the risk of being mulcted. Resort to such diversification adds more to the cost of capital than does the conventional diversification to avoid unsystematic economic risk. ${ }^{84}$ And in solne indetermmate number of cases there will be a failure to diversify adequately. ${ }^{85}$

It is hard to see the case connecting the necessity for disparate division with the merger and its gains. The only gam envisionable from the merger results from savings effected in combining the operations of

82. Values transferred to (or appropriated by) private parents are unavailable to public investors to offset the losses they incur as owners of stock in subsidiaries. And since parents can have many subsidiaries, but subsidiaries rarely lave more than one parent, the distribution of investment vehicles is skewed. See Bebchuk, The Case for Facilitating Competing Tender Offers: A Reply and Extension, 35 STAN. L. REv. 23, 27-28 (1982) (the probability of a company becouning an acquirer may differ from the probability of its becoming a target). It is possible to diversify ownership by investing $X$ dollars in one parent and $Y$ dollars in ten subsidiaries of other parents by allocating proportionate ownership (10\% of $\mathrm{Y}$ ) to each subsidiary. But the process imposes costs beyond those associated with diversification of portfolios for purely economic reasons, especially in view of the uncertainties about whether the enterprises will continue as subsidiaries and parents.

83. Costs of diversification are increased to the extent that the size of the mulcting turns on the parent's ability to manipulate the market at a particular time, because there is no assurance of lomogeneous mulcting potential anong parents.

84. See supra note 23 . If corporate management owns proportionately more shares of stock in parents than in subsidiaries (whicl seems likely), investors in subsidiaries who diversify into parents will inevitably be unable to enjoy enough of the gains of mulcting to offset their losses from being mulcted.

85. The inorality of a proposal which requires investors to diversify in order to protect themselves against the appropriative behavior of controllers, but which does not seek to prevent the appropriative behavior itself, is not self-evident. Whether or not that morality is relevant liere, the inescapable costs of such a proposal argue against it, at least in the absence of any assurance of meaningful gains that require such a rule. Easterbrook \& Fischel, supra note 8, at 713, appear to suggest that those who fail to diversify (statistically apt to be the least wealtlyy investors) should suffer the consequences. The alternatives available to such imvestors are to fail to diversify and run the risk of being mulcted or to buy mutual funds. 
parent and subsidiary. Those savings may result from economies of scale, elimination of duplicate costs, or financial synergy. If parent and subsidiary are engaged in contmuous transactions with each other, the merger will also eliminate both the temptation to overreach and the cost of monitoring that temptation. But those savings are imphicit in the two enterprises. Their realization does not depend upon the intercession of a third party with better ideas or the need to encourage momitors in the capital markets. If the discipline of the capital markets should effect such inergers, it does not require special tribute to be paid by the subsidiary's public stockholders to the parent.

Moreover, realization of the gains offered by such mergers entails no special cost to the parent, such as that incurred in searching for a buyer or planning innovation, or special risk to the parent, sucl as that involved in commencing a new business. Any transaction costs or search costs sliould appropriately be borne by the assets affectedeither by the parent's or the subsidiary's or the combined venture's. None of the gains rests upon such substantial added risks to parents that they ean claim the added returns of open ended disproportionate division. ${ }^{86}$ If compensation is needed, it is possible to claim it and atteinpt to justify it explicitly and allocate it in fixed amounts. Nor does the magnitude of expected gains from parent-subsidiary inergers call for large risk taking. Compared to the potential from third-party mergers, those gains are not apt to be significant. There is less reason for a special reward as an inducement to the parent to take the "risk" of combining witl a subsidiary than with a stranger. And a parent is not entitled to such a reward in the former case simply because of its techmical power to extort it. ${ }^{87}$

86. The parent's risk is much less than a stranger's, since its knowledge of the snbsidiary's affairs is inuch greater. And the parent's ability and teinptation to nnderpay is inuch greater than a stranger's since the counterpart to the snbsidiary in the arm's-length bargain would be uninhibited in seeking a higher price from the stranger.

One possible reason to induce the parent to combine with its subsidiary through the offer of a premium is to reimburse the parent for the risks entailed when the parent is called upon to finance a subsidary's opportunity to expand. See Dower v. Mosser Indus., 648 F.2d 183 (3d Cir. 1981). But if other sources of finance are equally available to the subsidiary, as they generally should be, there is no reason to honor the parent's claim to a disproportionate share. The parent is not required to lend money to the subsidiary, and the subsidiary is not required to expand. The issue thus renuining is whether the possibility that the parent is the lowest cost, or only, source of finance should permit it to overreach. The intrinsic difficulties in proving that the parent is such a source make its assumption as a premise for policy very doubtful. And the certainty of overreaching leaves the question whether the social or investor gain from the occasional case of "sole financial source" is worth assuming that all cases are in that category and hence permitting the regular overreaching and consequent imcrease in the cost of capital. A negative answer is more reasonable than an affirmative one.

87. The limitation thus imposed on the ability of the parent's stockholders to benefit froin disparate distribution of the subsidiary's assets among the subsidiary's stockholders is no inore or less appropriate than the limitations on their ability to benefit at the subsidiary's expense froin the 
In sum, the need for a rule of disparate treatment in order to encourage parent-subsidiary merger gains is problematic. The costs of such a rule are less doubtful. And any uncertainty as to whether, or the extent to which, the costs outweigh the gains inust reckon with considerations of fairness based on investor expectations. Those expectations impel enforcement of a rule of equality - or a requirement of advance warning to investors of the risks of unequal treatment. ${ }^{88}$

\section{Implementing the Requirement of Equal Treatment}

To conclude that the parent is entitled, in economic terms, to no more than its aliquot share of the value of the subsidiary's contribution to the combined enterprise leaves open the question of how to determine that share im the merged venture, and how best to assure equal treatment. In the case of a publicly held parent corporation, unlike the case of a private controller, it is possible to address the problem of equality by focusing on a larger constituency than the stockholders of the subsidiary. One can view all stockholders of both enterprises as the constituency to be treated equally by a simgle management having equivalent responsibilities to each. ${ }^{89}$ Equality in form may be achieved

parent's inside information about the subsidiary's affairs or the parent's power to self deal with the subsidiary.

The argument that parents should be allowed to appropriate subsidiaries' opportunities because appropriation is simply a substitute for foregoing the opportunity and instead covertly compensating themselves from the subsidiary's till, see Easterbrook \& Fischel, supra note 8, at 733-35, proves too much. So does the argunent that managers' freedom to appropriate corporate opportunities is a substitute for overt compensation. Both rest on the notion that the compensation for which appropriation of the opportunity is a substitute legitimately can be taken by the parent or management. But the legitimacy of such compensation, as of such appropriation, whether viewed as a matter of morals or of economics, depends at least upon the informed consent of the deprived stockholders after a showing of worth. That consent is sufficiently improbable that few managers would tolerate overtly informing stockholders of the possibility im advance of soliciting their $\mathrm{m}$ vestment, lest by so domg they alert them to the diversions to which it is assumed they consent, and thereby discourage investinent or raise the cost of capital. The notion that markets for managers exist and effect ex post settlements sufficiently precisely to substitute for exphicit ex ante arrangements is a bold hypothesis-but it is neither self-evident nor empirically supported. Indeed, existing experience and case law suggest that if there is such a market, it is not very effective. See Vagts, Challenges to Executive Compensation: For the Markets or for the Courts?, 8 J. CoRp. LAW 231 (1983).

88. Apart from any a priori basis for investors expecting the law to require equal treatment, there is no basis for beheving that investinent advisers wish to call such potential imequalities meaningfully to advisees' attention when recommending imvestment. And there is reason to believe investors do not intuitively alert themselves to such matters. See supra note 39 . Hence, it is not mappropriate to require any ambiguities on that score to be cleared up by explicit adinonition to imvestors from those soliciting imvestınent. Tellingly, those in the busimess do not seem willing to clear up the ambiguity. Presumably they recognize that adopting and disclosing a disparate sharing rule would raise capital costs and.keep more imvestors away than would continued silent rehance upon the current ambiguous conditions. See N. BuCHANAN, supra note 15, at 458-59.

89. See Brudney \& Chirelstein, supra note 41, at 318-19; Berle, The Theory of Enterprise Entity, 47 CoLUM. L. REV. 343, 355-58 (1947). 
by issuing stock of the parent to the minority stockholders of the subsidiary or stock of a third corporation into which both parent and subsidiary are counbined to the stockholders of each.

To be sure, this still leaves the question whether the price (in new stock) thus paid for the subsidiary's assets is fair-i.e., results in a substantively equal division of the combined assets among all the stockholders. In the absence of any basis for identifying, quantifying, and coinpensating for the contribution (or components of the contribution) of each company to the combined venture, substantive equality is best effected by requiring each enterprise to share with the other in the proportion in which each contributes value to the new venture. Precisely such proportionate sharing underlies the equal treatment of shareholders on the formation of a corporation. Each contributing investor participates in the enterprise by receiving stock proportionate to the value of his contribution to it, but each receives the saine participation per dollar contributed. Proportionate sharing in the parent-subsidiary merger by the shareholders of each corporation can be effected in the same manner. Each contributing company is allocated the proportion of the surviving coinpany's stock which corresponds to the proportionate value of each coinpany's contribution to the combined enterprise. This allocation may then be divided equally per share alnong each corporation's stockholders. The single set of managers of both ventures thus fulfills its fiduciary obligations to each set of stockholders. The managers do not favor one set of stockholders over the other; instead, they treat each set as if they were pooling or combining assets at arn's length with the benefit of full information. ${ }^{90}$

Elsewhere it has been suggested that sharing of the gains froin the merger is a rational expectation of investors and that those gains should be shared ${ }^{91}$ in proportion to the value of each corporation's contribu-

90. It has been suggested that the duties of trustees to separate funds are analogous to those here at issue. See Brudney \& Chirelstein, supra note 41, at 319. The analogy has been disputed. See Lorne, A Reappraisal of Fair Shares in Controlled Mergers, 126 U. PA. L. Rev. 955, 970-83 (1978). But nothing in the existence of two sets of stockholders sharing, in part, a joint venture suggests that either set of stockholders does, or should, expect to be required to make sacrifices in order to combine with the other, or mature a corporate opportunity for both.

91. Since parent-subsidiary mergers are not exercises in altruism, it is reasonable to expect only gains from the merger. But it is possible that there may be losses, and if a loss results, the subsidiary should share it unless the parent is at fault in determining the contributed values and the sharing allocation. Sharing in proportion to contributions imphies that if the combined enterprise is worth less than the sum of its parts the subsidiary's stockholders share the loss. Since the parent is effecting the merger unilaterally, the question arises whether it should take all the risk of loss (in which case the sharing formula here presented shortchanges the subsidiary's public stockholders) or whether it should bear the loss only if it is at fault-i.e., if it is culpably contributing less in value than it claims credit for contributing, see, e.g., Goldberg v. Meridor, 567 F.2d 209 (2d Cir. 1977), cert. denied, 434 U.S. 1069 (1978), but not if its presumably optimistic expectations fail to materialize for reasons beyond its ken or control. 
tion to the merger. ${ }^{92}$ Courts have received the suggestion less than wholeheartedly. ${ }^{93}$ And issues have been raised by commentators as to whether sharing is necessary or appropriate, and if so, how to determine the value of each corporation's contribution, and whether to include any (or what) portion of the gains (or losses) from combining. ${ }^{94}$ But that some sharing is, and ought to be, the rational expectation of investors is not seriously questioned. ${ }^{95}$ To concede that more than one sharing formula is rationally possible and that each, including the one previously suggested, is vulnerable to criticism, ${ }^{96}$ neither precludes

92. See Brudney \& Chirelstein, supra note 41 .

93. That a parent is required to accord "fair" treatment to a subsidiary in a merger is the explicit teaching of the courts, in Delaware and elsewhere. See, e.g., Harman v. Masoneilan Int'1, Inc., 442 A.2d 487 (Del. 1982); cases analyzed $i d$. And that teaching is not obliterated by the Delphic utterances of the Supreme Court of Delaware in Weinberger v. UOP, lnc., No. 58 (Del. Feb. 1, 1983).

While the Delaware courts are less than clear about the meaning of "fair" treatment, there is no doubt that they contemplate some sort of sharing of the benefits of the merger $\mathrm{m}$ cases challenging parent-subsidiary inergers for "fairness." Delaware's past refusal to permit the availability of the appraisal remedy to preclude a challenge for unfairness, see Simger v. Magnavox Co., 380 A.2d 969, 977 (Del. 1977); Roland Int'l Corp. v. Najjar, 407 A.2d 1032, 1034 (Del. 1979), rested on the assumption that the latter remedy offered more to the challenger than did appraisal-i.e., an accounting for past misbehavior and a sharing in the benefits of the merger. See Lynch v. Vickers Energy Corp., 429 A.2d 497, 505 (Del. 1981) (damage computations); Harman v. Masoneilan Int'l, Inc., 442 A.2d 487, 500 n.23 (Del. 1982) (same). See also Gabelli \& Co., Inc. Profit Sharing Plan v. Liggett Group, Inc., 444 A.2d 261 (Del. Ch. 1982).

To be sure, Weimberger v. UOP, Inc., No. 58 (Del. Feb. 1, 1983), rejected the teaching that an action to test fairness of price is not precluded by the existence of the appraisal remedy-at least in cash-out cases. But Weinberger contemplates the continued coexistence of both remedies in some cash-out cases ("fraud, misrepresentation, self-dealing, deliberate waste of corporate assets or gross and palpable overreaching") and possibly even less restrictedly in non-cash-out mergers. More important, Weinberger, in "liberalizing" the relief available under the appraisal remedy, imphes some sort of sharing, but leaves the anatter frightfully opaque. $C$. Dofflemyer v. W.F. Hall Printing Co., [Current] FED. SEC. L. REP. (CCH) I 99,125 (D. Del. Jan. 28, 1983). See also N.Y. Bus. CORP. LAW $\$ 623(\mathrm{~h})(4)$ (McKinney 1982).

94. See, e.g., Carney, supra note 42, at 116; Easterbrook \& Fischel, supra note 8; Lorne, supra note 90; Toms, Compensating Shareholders Frozen Out in Two-Step Mergers, 78 CoLUM. L. REV. 548 (1978); Weiss, supra note 41.

95. Even those who believe that rational investors would consent ex ante to controllers' appropriation of more than their aliquot share and that an efficient market determines the limit of such appropriation contemplate sharing in some minimum amount of the merger gain. The objection to sharing based on the imability to find, or difficulty in applying, an appropriate formula, see Easterbrook \& Fischel, supra note 8, at 728, cannot justify otherwise indefensible allocations of resources or frustration of investors' expectations unless no tolerable fornula is feasible-a condition which remains to bo demonstrated.

96. Commentators have criticized the suggestion that in a parent-subsidiary merger, the merger gains should be shared in proportion to the value that each corporation's stockholders contribute to the inerger. See Carney, supra note 42, at 116 n.188; Lorne, supra note 90, at 973-83; Toms, supra note 94, at 569-75. To the extent that the criticism is addressed to the failure of the formula to require compensation for identifiable costs or contributions which can be shown to produce specific mcreases or decreases in the value of the combined enterprise, it is vahid but irrelevant. See id. at 569-75. The formula is directed at the phenomenon of undisentangleable consequences of contributions. Another valid but miscast criticisin is that the market prices of 
sharing nor denies the preferability of one formula to others.

Difficulties posed by a payout which is in any form other than the parent's or consolidated company's common stock, are avoided if that stock is the currency of the merger. ${ }^{97}$ Payout in the form of its common stock by the consolidated enterprise conforuns to, and facilitates application of, the rule of equal treatment of stockholders. ${ }^{98}$ In theory, measuring equahity of treatment by the proportion of the surviving company's common stock distributed to the participants need not pre-

parent's and subsidiary's stocks is an erroneous measure of the contributed value. See Carney, supra note 42 , at $116 \mathrm{n} .188$. The criticism is plausible, but mistakenly attributed to the sharing proposal. Cf. Brudney \& Chirelstein, Corporate Freezeouts, supra note 41, at 1373 n.35, 1374 n.36 (arguing that reliance on market price of the parent and subsidiary's stock in determining sharing is misplaced). Another criticism is that the formula looks only to gains, but fails to take account of losses. See Toms, supra note 94, at 570-71. But see supra note 91.

A less valid challenge is addressed to the formnla's predicating sharing on the ratio of values contributed by parent and subsidiary rather than on other ratios, such as of assets or sales. See Easterbrook \& Fischel, supra note 8, at 728; Lome, supra note 90, at 981-82. But it is the value or amount contributed by each of the merging enterprises that is being subjected to the risk of common stock ownership in the combined enterprise. The analogy is to an investor's cash contribution to a corporation. Sales or gross assets are totally irrelevant notions. Returns for the risk thus taken should be in proportion to the amounts contributed. All costs and savings are thus lumped and prorated, and levels of risk equilibrate in calculating values contributed.

97. Some of the criticisin of the proposal for sharing is addressed to problems in calculation and to the impracticality of a payout that is in a forn other than the parent's common stock. See, e.g., Lorne, supra note 90, at 983-87. For the most part, as Lorne recognizes, those criticisms becoine irrelevant when the model contemplates payout in the parent's common stock. Id, at 983 . It is uot necessary-either as a matter of efficiency or as a matter of equity-for longtime parents to be able to freeze out minority public holders of subsidiaries for cash or for senior securities. Merging thein out for the parent's common stock is both appropriate and lawful.

If the diffculties entailed in cashing then out are not insurmountable, there is no reason to require only all-stock mergers. And at least if the subsidiary's public stockholders are to be given cash or senior securities in an amount equivalent to the estimated value of the common stock of the combined enterprise to which they would be entitled in an all-stock nerger, the difficulties seem surmountable. The flaws in market prices, even of the merged company's stock over a period, suggest that an "intrinsic" valuation of the combined enterprise is required. That such a process is feasible, albeit not without a need for close judicial supervision, is suggested by the valuations regularly made of the cash values of packages of securities offered as the second steps in teuder offers. On the other hand, the cost to outsiders and the uncertainties of reaching such valuations in a contested proceeding wonld be avoided by requiring the longtime parent-subsidiary inerger to be on an all-stock basis. That process would also avoid the necessity for determining the tax eost of a payout in cash or senior securities, for which the minority is entitled to compensation. See also Weimberger v. UOP, Inc., 457 A.2d 701 (Del. 1983). Cf. Toms, supra note 94, at 575-85 (suggesting a "modified intrinsic value" approach which would provide frozen-out investors with compensation for tax and reinvestunent costs).

98. To be sure, no matter what formula is invoked to determine the division between parent and subsidiary, formally identical treatment of the subsidiary's stockholders in dividing its returns is possible. But sharing between the two companies by allocating new common stock on the basis of the proportionate values of their eoutributions to the combined enterprise inost closely matches the mode of sharing eontemplated by the initial stock participation in a corporate venture: each shareholder receives the same participation per dollar contributed, but the relative value of the share received is determined by the relative value of the contributions made on fornation, or on later eombining participations. 
clude use of cash or other currency to pay off the public stockholders of the subsidiary. So long as they receive a quantity of such other currency that is the effective equivalent of the requisite common stock of the survivor, the principle of equality will be adequately vindicated. If practical difficulties in valuation are deeined too costly, ${ }^{99}$ neither law ${ }^{100}$ nor policy need preclude requiring inergers of long time parents and their subsidiaries to be consummated only on an all stock basis.

Prescribing a payoff in common stock of the surviving coinpany (not to inention cash or senior securities) does not eliminate or mimmize the difficulties inevitably encountered in valuing the disparate assets which each company contributes to the surviving enterprise. Simce market prices are not reliable, "intrinsic" valuation is required, with all the attendant costs and obstacles for those who would challengc msiders' estimates of the enterprise's expected returns and risk lcvel. Those difficulties impede achievement of the desired equality or more than an approximation of it. ${ }^{101}$ Eliminating or reducing them would be facilitated by adoption of procedures utilized in similar contexts, such as obtaining assistance of government-appointed negotiators for the public stockholders, the intervention of an administrative agency, or more focused and critical judicial scrutiny than courts have given in the past.

\section{Corporate Purchase of Its Own Shares}

Like a dividend distribution, a corporate purchase of its own stock is a distribution of a part of the corporation's assets to its stockholders. ${ }^{102}$ But it is a distribution which differentiates among stockholders. The sellers get cash and the surviving stockholders receive larger proportionate clainis to the remaining assets. As with dividends or distri-

99. See supra note 97.

100. See supra note 69.

101. It has been suggested that the sharing proposal is defective because it fails to require the parent to offer the subsidiary to strangers in order to test the propriety of the merger price. Chirelstein, Sargent \& Lipton, "Fairness" in Mergers between Parents and Partly-Owned Subsidiaries, 8 INST. ON SEC. REG. 273 (1977); cf. Weiss, supra note 41, at 679-80. That suggestion, however, goes to the valuation process, not to the sharing requirement. To the extent that the operating or financial synergy resulting from the parent-subsidiary merger might not be available to strangers, the parent is likely to be able to offer the highest price. But whether the subsidiary must be offered for sale in order to test whether the parent is offering the highest price is a difficult question. It is not, however, the same question as whether a private controller must offer the company for sale or refrain from going private. Not only are the social gains from coinbining public parent and subsidiaries potentially more significant than those from going private, but because the minority can be given the equivalent of continued participation in the combined venture, there is less necd to force the equivalent of a sale to a stranger.

102. The Model Business Corporation Act treats the two processes as identical for purposes of measuring the permissibility of distributions. See MODEL BusINEss CORP. ACT \& 2(i) (1979); Committee on Corporate laws, Section of Corporation, Banking and Business law, abA, Changes in the Model Business Corporation Act-Amendments to Financial Provisions (1979), reprinted in 34 Bus. LAW. 1867, 1869 (1979). 
butions in dissolution it is theoretically possible that the transaction treats all stockholders equally in substance, notwithstanding the formal difference in treatment. For instance, the amount paid per share to selling stockholders may be equal to the value per share remaining to the surviving stockholders after repurchase. Departure froin formal equahity, however, exposes mvestors in theory to the possibility, and in practice to the probability, that different values will be allocated among shareholders. The probability of such differential treatınent is not less in the case of stock repurchases than it is in the case of distributions of different kinds of property as dividends or in the case of dissolution.

A corporation may repurchase its stock without apparently imtending to convey more to one group of its stockholders than to another. Such "neutral" corporate purposes may include partial liquidation as a result of contracted operations, ${ }^{103}$ performance of household functions, ${ }^{104}$ or creation of benefits (largely tax) for its stockholders. ${ }^{105}$ Generally, however, it is the effect, if not the purpose, of the repurchase to distribute more (or less) to one group of stockholders than to another. Thus repurchase is, on occasion, simply an effort to buy the stock cheaply, either because controllers know favorable corporate information not known to the market, or because management views the stock as its best investment opportunity. ${ }^{106}$ On the other lrand, it is not unknown for a firm to pay an excessive annount (either above market or above expected market) in order to maintain its stock price agamst intimations of unfavorable developments, ${ }^{107}$ to preserve incumbents' control, ${ }^{108}$ or to bail out insiders. ${ }^{109}$

State statutes permit a corporation to repurchase its stock at the

103. Such a repurchase is to be distinguished from going private. In the latter case, the purpose is less to contract than to eliminate or significantly reduce the number of publicly held shares. Furthermore, going private transactions are rarely even colorably volitional on the part of the sellers. Cf. supra note 53.

104. Repurchase serves to fulfill household functions, such as eliminating small lots, buying out retiring employees or settling disputes over indebtedness. $C f$. MODEL Business CORP. AcT \& 6(a)-(d) (1979).

105. See Chirelstein, Optional Redemptions and Optional Dividends: Taxing the Repurchase of Common Shares, 78 YALE L.J. 739 (1969).

106. Brigham, The Profitability of a Firm's, Purchase of Its Own Stock, CaL. MGMT. Rev., Winter 1964, at 69; $q f$. M. Bradley \& L. Wakeman, supra note 28; studies summarized id. at 3-6.

107. The effort may also be to raise the price of the stock in order to use it as currency in acquisitions or to induce conversion, see Davis v. Pennzoil Co., 438 Pa. 194, 264 A.2d 597 (1970). Or such a premium may result simply because the stock sells on the market at less than the value managenent or the controllers put on it.

108. See Petty v. Pemitech Papers, Inc., 347 A.2d 140 (Del. Ch. 1975); M. Bradley \& L. Wakeman, supra note 28; Brudney, supra note 13; L. Dann \& H. DeAngelo, Standstill Agreements, Privately Negotiated Stock Purchases and the Market for Corporate Control (Feb. 1982) (unpublished inanuscript forthcoming in volume 11 of the Journal of Financial Economics).

109. See, e.g. , Bradley \& Wakeman, supra note 28; Nussbaum, Acquisition by a Corporation of Its Own Stock, 35 Colum. L. Rev. 971,986 (1935). 
discretion of the directors if the corporation has a source in surplus for the funds used in the repurchase. ${ }^{110}$ Such statutes do not require prorata repurchase. Federal securities laws contemplate repurchases but require that the corporation adequately disclose the relevant considerations to the sellers. ${ }^{11}$ Fiduciary notions in the cases impose both restrictions on directors' discretion and disclosure obligations in order to preclude a use of corporate assets which favors insiders. ${ }^{12}$ Inplicit in the cases is the concept that the distribution of corporate assets embodied in the repurchase should not result in selling stockholders being treated inore, or less, favorably than surviving stockholders. ${ }^{113}$

While the case law thus suggests the principle of equahty in substance, it effectively permits its avoidance in practice. The considerable difficulties in establishing what the stock is "worth" or that the corporate decision makers are favoring themselves ${ }^{114}$ have made the principle of equality a porous protection for outsiders. Fully effective application of the principle in the context of repurchase requires formally equal treatment-i.e., categorically prohibiting repurchases by

110. See Del. Code ANN. tit. 8, $\S \S 160,172,174,223$ (1974 \& Supp. 1982); N.Y. Bus. Corp. LAW §§ 513-516, 719 (McKinney 1963 \& Supp. 1982); see also Martin v. American Potash \& Chem. Corp., 92 A.2d 295 (Del. 1952); Snyder v. Memco Eng'g \& Mfg. Co., 23 A.D.2d 671, 257 N.Y.S.2d 213 (1965).

111. See Ward La France Truck Corp., 13 S.E.C. 373 (1943); Northern Trust Co. v. Essancss Theatres Corp., 103 F. Supp. 954 (N.D. Ill. 1952); Kennedy, Transactions by a Corporation in Its Own Shares, 19 Bus. LAw. 319 (1964); Malley, Corporate Repurchases of Stock and the SEC Rules: An Overview, 29 Bus. LAw. 117 (1973); 17 C.F.R. § 240.13e-4 (1982). The lnvestment Company Act authorizes restrictions on repurchase subject to SEC permission. See Investment Company Act of 1940 § 23(c), 15 U.S.C. § 80a-23(c) (1976); 17 C.F.R. § 270.23c-1(a) (1982); see also Alnan, Inc., [Current] FED. SEC. L. REP. (CCH) I 77,317 (SEC Oct. 6, 1982).

112. See Brudney, supra note 13; Note, Buying Out Insurgent Shareholders with Corporate Funds, 70 YALE L.J. 308 (1960); Wood v. MacLean Drug Co., 266 Ill. App. 5 (1932); MacGill v. MacGill, 135 Md. 384, 109 A. 72 (1919).

The SEC long called attention to, and sought to restrict the manipulative possibilities generated by, corporate repurchases. See Note, Corporate Stock Repurchases Under the Federal Securilies Laws, 66 Colum. L. Rev. 1292 (1966); Proposed Rule 13e-2, Securities Exchange Act Release No. 17,222, [1980 Transfer Binder] FED. SEC. L. REP. (CCH) I 82,669 (Oct. 17, 1980); Securities Exchange Act Release No. 19,244, [1982 Transfer Binder] FED. SEC. L. REP. (CCH) ๆ 83,276 (Nov. 17, 1982); Securities Exchange Act Release No. 19,245, [1982 Transfer Binder] FED. SEC. L. REP. (CCH) I 83,277 (Nov. 17, 1982). That the Commission has withdrawn its proposal to prescribe general antimanipulative terms and conditions for repurchase, in favor of a safe harbor provision, Rule 10b-18; Securities Exchange Act Release No. 19,244, [1982 Transfcr Binder] FED. SEC. L. REP. (CCH) I 83,276 (Nov. 17, 1982); Securities Exchange Act Rclease No. 19,245, FED. SEC. L. REP. (CCH) I 83,277 (Nov. 17, 1982), reflects the deregulatory market orientation of that agency. It does not eliminate manageunent's teinptation to unanipulate or the need to proscribe, or the statutory prohibitions against, manipulation.

113. "Favorable" treatment of controlling insiders could be immediately economic, as in price advantages to thein on bailing thein out or on buying from outsiders. Or the favorable treatment may be indirect, as in the use of corporate funds to preserve their control. See, e.g., Petty v. Penntech Papers, Inc., 347 A.2d 140 (Del. Ch. 1975); Cheff v. Mathes, 199 A.2d 548 (Del. 1964).

114. See Brudney, supra note 13 , at 272-75. See also supra note 30. 
publicly held corporations. Or, the principle can be implemented somewhat less effectively, but possibly at a lesser cost, by requiring prior court or agency approval of the transaction to assure substantive equality.

To determine whether the principle of equality should be thus more (or less) rigidly enforced, it is necessary to consider the advantages of repurchase which are lost by a categorical prohibition, and whether obtaining those advantages is worth the cost of the present rule which permits considerable evasion of the substantive principle of equality.

The advantages claimed for the firm or society from permitting repurcliases leave much to be desired as justifications. That the value of the enterprise is not augmented by the repurchase is plain. To characterize the repurchase as a preferred imvestment of corporate assets does not mean that such an mvestment of funds mcreases the profitability or decreases the risk of the enterprise's operation. On the contrary, repurcliase dismvests funds, and simply redistributes share ownership in the same productive assets. Such a result could as easily lave been effected by paying a cash dividend and letting stockholders sell stock to each other. To be sure, permitting repurcliase offers another means to facilitate distribution, and avoids management retention of corporate funds for which investors may find better use. ${ }^{115} \mathrm{But}$ such a purpose is unlikely to be implemented, particularly by controlling stockholders.

The value of permitting controllers to use corporate assets to buy off raiders has long been disputed. A priori, such use of corporate funds is likely to benefit neither society nor incumbent public stockholders. It is generally not likely to further the best use of corporate assets. As lias been noted, permitting management to buy off raiders, even in those cases in which it is claimed to be the best use of the corporation's assets (i.e., to avert a takeover by a less efficient or inore corrupt controller) involves policing costs and an imdeterminate number of evasions that can easily outweigh the occasional benefit. ${ }^{116}$ Permittimg controlling stockholders to buy off raiders implicates a more certain net cost.

The tax advantage to stockholders of a repurchase instead of a dividend does not augment the corporation's wealth. At best, if transfer payments were possible, or if the corporate inanagement attempted to fix a repurchase price that required sellers to share their tax advantage to some extent with the nonselling stockholders, there would be no

115. See supra note 53.

116. See Brudney, supra note 13. 
increase in the productive wealth of the society attributable to the real assets in corporate solution. The enhancement of corporate wealth by a repurchase price that reflects a give-up by sellers of some of their income tax advantage is simply a transfer payment to the surviving stockholders, who ultimately will pay their tax if they obtam the transfer payment individually by dividend, hquidation, or sale of stock. And the difficulty in determining the appropriate amount of such transfer payments suggests that there would inevitably be inequality in sharing the sum of the surviving stockholders' price advantage and the seller's tax advantage.

It has been suggested that stock repurchase transactions enhance the pricing efficiency of the market, and presumably cognate capital allocational efficiency. ${ }^{117}$ If imitiated by management in the absence of controlling stockholders, such transactions escape many of the objections of insider tradimg. Even if management repurchases in a bona fide effort to raise prices, however, there is reason to question whether either allocational or market efficiency would be enhanced. ${ }^{118}$ But

117. See Manne, Insider Trading and the Law Professors, 23 VAND. L. REv. 547, 565-66 (1970); Demsetz, Peffect Competition, Regulation, and the Stock Market, in Economic PoLICY and the Regulation of Corporate Securities 1, 14 (H. Manne ed. 1969); W. Baumol, The STOCK MARKET AND ECONOMIC EFFICIENCY 63 (1965). But cf. Berle, The Impact of the Corpora. tion on Classical Economic Theory, 79 Q.J. EcoN. 25 (1965) (suggesting the diminishing importance of the securities market as a source of risk capital).

118. Arguably, a management which "believes" price is lower than "true" value but is unable to persuade the market to equalize the two (notwithstanding the fullest feasible disclosure of all relevant corporate information) will, by judicious repurchasing, bring price closer into line with value sooner than would otherwise occur in a market unstimulated by such repurchasing. Some doubt is cast upon that argument, lowever, by the suggestion that the market falls after the repucluase program stops. See Hetherington, supra note 9, at $236 \mathrm{n} .169$.

In theory, market price reflects the bids and asks of rational, willing buyers and sellers who bring to bear on the transactions their judgment about the value of the particular stock in coinparison with other trading or investment opportumities. When the corporation buys its own stock it may, as a fornal unatter, be inaking a similar judgment-it is better to invest in its own stock than in some other asset. However, notwithstanding the social values claimed for use of inside information, see H. MANNE, INSIDER TRAINING AND THE STOck MARKET (1966), to allow market price to be set by corporate purcliases can have sigmificant distorting effects on prices presulnably set in a free market. See Halsey, Stuart \& Co., 30 S.E.C. 106, 112 (1949). Those purchases inject variables not generally associated with the market's pricing function or the opportunity sets of outside buyers. If the variable is hard "inside" information, managcment ought to disclose it in the interest both of inarket efficiency and its obligation to all the firm's stockholders.

A more complex problem is presented if it is "soft" undisclosable (because too indeterminate) information combined with managerial judgment which the market contemporaneously does not share. It is reasonable to suppose that in such circumstances management has a favorable bias about the future which a more objective market does not share at the time and often will not share when the future arrives. Such corporate repurchase creates a inore or less systematic likelihood of later market disagreement with management's earlier judgment. No social gain follows from the process. All that is involved is favoring one group of stockholders over another-unless the market's pricing function is enhanced.

The question is not merely whether the direction of the price movenent which management's repurchase will effect is inore likely to be right than wrong in view of management's bias. It is 
when controlling stockholders initiate a repurchase transaction, the objections to insider trading apply with comparable force. ${ }^{119}$ Hence, the value of such transactions for the pricing efficiency of the market must be weighed agaimst both the inipediments they may create to achieving that goal and the cost of permitting diversion of values to insiders. ${ }^{120}$

If repurchases provide no enhancement of corporate wealth and hittle enhancement of market efficiency, the only other value to be weighed $\mathrm{im}$ assessing a rule precluding, or requiring approval for, repurchase is the availability to investors of a choice to retain or to sell the stock at what they consider advantageous prices. ${ }^{121}$ There is room to argue, even in a context in which management is not dominated by any shareholder group, that the rule of equal treatment, or management's duty to all stockholders, cannot be satisfied by the offer of such a choice. ${ }^{122}$ But even if it can, the value thus urged-both for sellers and for those who remain stockholders ${ }^{123}$-turns on whether the choice

whether, in view of the magnitude of the induced movement, the direction is likely to be right sufficiently more often than the narket would be if it had all the information which management is unable to disclose at the time of repurchase. In light of other, corrupt as well as biased, factors that allowing repurchase introduces, it is not irrational to prefer market determination of price on the best disclosure management can make to a price influenced by managerial use of corporate cash.

119. Controlling stockholders have reason to withhold disclosable information in order to induce bargain purchases by the corporation. The limits of the law requiring disclosure import a wide margin for such withholding. If, as is probable, controllers ntilize that margin fully, market price may be less accurate under a regine permitting repurchase (with its imcentive to withhold imformation) than under a regime forbidding repurchase, at least for firms with controlling stockholders.

120. The signalling effect of repurchases is beth less communicative and more confusing than the signalling effect of dividends. See Asquith \& Mullins, The Impact of Initiating Dividend Payments on Shareholders' Wealth, 56 J. Bus. 77 (1983); Dann, supra note 28; Vermaelen, supra note 28.

121. Cf. supra note 50.

122. See Brudney, Going Private, supra note 52, at 1046-48. The propriety of requiring stockholders to choose between remaining and selling when management proposes an investunent in new assets does not demonstrate the propriety of forcing a choice between remaiming and selling when the "investment" which management makes is in its own stock. The possibility of social gain in the former is wholly lacking in the latter.

123. It has been suggested that if stockholders were separable into (1) investors who invest on long-term expectations and trade in the short term only in response to unexpected personal needs, and (2) speculators, short-sellers and arbitrageurs who trade primarily im response to price movements, Shonfeld, Business in the Twenty-First Century, 98 DaEDalus 191, 201 (1969); see also H. MANNE, supra note 118, at 94-96, the former are systematically likely to benefit, and the latter to lose more or less randomly, from corporate repurchase on favorable inside information. See H. Tobin, Should Corporations Be Permittcd To Purchase Their Own Shares? 31-35 (1980) (unpublished manuscript on file with the California Law Review). The total number of shareholders will thus gain (if short sellers are not considered shareholders) and long-term investors will be preferred over short-term traders. Whether long-term investors are nore deserving than short-tcrm traders, or whether any such distinction anong investors would justify departure from the rule of equal treatment-as a inatter of efficiency or as a nuatter of expectations or equity-requires further inquiry. But given a model with a controlling group of stockholders, the likelihood of per- 
offered is volitional or is skewed against the outsider.

The volitional character of the repurchase transaction is not always clear. When insiders' shares are being bought the transaction is effectively unilateral and no volition by outsiders is involved. When outsiders' shares are being bought, the volitional character of the sellers' acts depends upon how well informed they are or how coercive the tender offer is. Hence, formally expanding the choices available to stockholders by permitting offers to repurchase is not always preferable to precluding that choice. Expansion of opportunities for choice is an independent good only if the choice is not confined to a context in which it is nore probable (rather than less probable) that the noncontrolling seller or buyer will be a loser-i.e., will sell at less, or effectively buy at inore, than the value of the stock. If there is a systematically higher probability that the outsider will lose rather than gam, offering the choice is not a good to be encouraged, unless the probabilities are adequately explained.

Avoidance of such a systematically skewed choice requires adequate disclosure of relevant information. But fulfillment of that requirement is difficult even in the best of circunistances-i.e., where selfinterest does not distort the controller's decision to repurchase or the completeness of the inside information distributed to the outsider. ${ }^{124}$ Given such self-interest, norinal "fraud" law, including Rule 10b-5, offers only inodest help. ${ }^{125}$ Sellers are systematically likely to be deprived of the opportunity to make an adequately inforined choice. Whether or not pressure to disclose such information will result in any significant cost to the corporation, ${ }^{126}$ added costs to investors will result froin efforts to enforce production and communication of such ainbiguous information.

The question is whether it is worth exposimg all stockholders and society to the information disadvantage or to those costs in order possibly to reduce some stockholders' personal income tax by an ambiguous tax avoidance device ${ }^{127}$ or to give thein the opportunity to sell stock to

sonal gain to them from use of inside information sets up a different equation than that applicable to repnrchase by a relatively disinterested management.

124. See Brudney, supra note 52, at 1046-48. Insiders will rationally decline the risk of being found liable for erroneously making the estimates or projections which are necessary to be rcvealed in order to make adequate disclosure.

125. Even federal disclosure requirements for issuer tender offers, see 17 C.F.R. $\$ 240.13 \mathrm{e}-4$ (1982), leave room for controllers to enjoy "play" in the use of inside information. But cf. supra note 28.

126. Compare Brudney, Dividends, Discretion, and Disclosure, 66 VA. L. Rev. 85, 116-18 (1980) (examining appropriate disclosure requirements for dividend distributions), with Fisclel, The Law and Economics of Dividend Policy, 67 VA. L. REv. 699, 717-25 (1981) (arguing against mandatory disclosure of information regarding dividend policy).

127. Whether a repurchase (in preference to a dividend) motivated solely or even primcipally 
the company at prices above market. Even in the case of a management not subject to dominant stockholders, repurchase is sufficiently difficult to momitor and insufficiently valuable to society to raise doubts that its benefits to some stockholders are worth its probable costs to others. ${ }^{128}$ But if the likely presence of market imperfections (i.e., inside information or manipulated prices) is coupled with the controllers' temptation to create or exploit those imperfections, the inatter is less doubtful. In those circumstances, the costs of a rule under which controllers can-and in their own interest will seek to-benefit themselves at the expense of outsiders, weigh more heavily against the personal cost to outsiders of a categorical prohibition or a rule requiring prior court approval.

In sum, for corporations having controlling stockholders, there is good reason to adopt a categorical prohibition against most ${ }^{129}$ repurchases. ${ }^{130}$ And for repurchases by large public corporations without controlling stockholders there is reason to consider at least a requireinent of prior approval by the courts or an administrative agency. ${ }^{131}$ Comparable restrictions in other countries with inodern industrial and financial institutions suggest that such restrictions are not incompatible with a feasible corporate jurisprudence. ${ }^{132}$

by the expected tax consequences to the stockholders is, or should be, allowed to produce capital gain treatment is a nice question. See Bacon, Share Redemptions by Publicly Held Companies: A New Look at Dividend Equivalence, 26 TAX L. REv. 283 (1971); Chirelstein, supra note 105.

128. But cf. supra note 123.

129. Exceptions are needed for close corporations and for repurchases: for household cleanup, such as eliminating fractional shares or reducing odd lots, see Securities Exchange Act Release No. 19,246, [1982 Transfer Binder] FED. SEC. L. REP. (CCH) ๆ 83,278 (Nov. 17, 1982), or in special contexts from particular persons, such as debtors who are compromising or paying debts, disseuters in appraisals, or retiring einployees.

130. It does not alter the conclusion urged in the text that controllers may, subject to fiduciary and disclosure obligations, use their own funds to purchase corporate stock. Different considerations of social utility weigh the balance against a categorical prohibition of personal purchase by controllers. See Brudney, Going Private, supra note 52, at 1053-54.

131. The difficulty in determining whether a controlling group exists is relevant to whether to invoke only the less rigorous remedy. That difficulty may justify imposing the broader prohibition in all cases rather than merely where a controlling group exists.

132. English law has recently moved from prohibition of repurchase without court approval, see L. GowER, supra note 37, at 225-28 (4th ed. 1969 \& Supp. 1981), to permitting repurchase under restricted conditions, see Department of TRADE, The PuRChase BY a CompanY of ITS OWN Shares (1980) (Cmnd. 7944); Coinpanies Act of 1981, ch. 62, $\$ \S 46-48$. Other countries still retain the prohibition. See H. Ford, PRINCIPLeS OF COMPANY LAw 162-64 (1974) (Australia). Cf. Investment Company Act of 1940, \& 23(c), 15 U.S.C. \& 80a-23(c) (1981); 17 C.F.R. $\$ 270.23 c-$ I(a) (1981) (authorizing restrictions on repurchase subject to SEC permission). In Western European countries, corporate purchase of shares is governed by somewhat less rigorous restrictions. These range from a flat prohibition against such purchase without court approval to prohibitions with increasingly broad exceptions. See E. SteIN, Harmonization of European Company Laws 322-25 (1971); CoMpanY LAW IN Europe 94-95 (S. Frommel \& J. Thompson eds. 1975) (Belgium); id. at 158 (Denmark); id. at 198 (France); id. at 276 (Ireland); id. at 396 (Netherlands); id. at 564-65 (United Kingdom); id at 309 (Italy). A fat prohibition has been proposed for Euro- 


\section{E. Summary}

If we distance ourselves from particular types of transactions, and look at the general pattern of the transactions, we see that all involve essentially unilateral action by controllers who are tempted and able to take more than their ahquot shares of the firm at the expense of the minority. Since third parties are not involved $\mathrm{m}$ bidding, they are not available to set a floor or indeed a fair value for the prices at which minorities are expropriated. And the susceptibility of inarket price to controller manipulation im anticipation of the transactions makes that price meffectual to assure the minority a floor that will leave them "no worse off." There is thus no reason for the minority to consent to such arrangeinents-ex ante or otherwise. Any rule authorizing them will substantially increase the cost of inducing public imvestinent. Moreover, a rnle of unequal treatment offers controllers the temptation to engage im wasteful transactions solely for the purpose of realizing personal gams.

What reason, therefore, justifies a rule allowing controllers to divert any part of the minority's aliquot share to themselves? Since the transactions are entirely mternal resluuffes, no gain from new contributions-tangible or imtangible-from third parties enters into the costbenefit calculations. Self-generatcd increases in value claimed for the enterprise, even if occasionally substantial, will normally be less than would be expected from third-party intervention. And little, if any, of those gains can be shown to require disparate division of assets in order to obtaim controllers' consents. In an internal rearrangement, the controllers' knowledge of the relevant facts reduces the likelihood that the process of seeking sucl gams nccessitates the incentive of disparate division as a means to compensate controllers for special costs or unshared risks from the transactions. Hence a rule of unequal treatment provides no apparent social advantage. The claim for net gains from such a rule rests on tidy assumptions which ignore imstitutional frictions and market imperfections.

If, as appears likely, investors have reason to expect equal treatment in distributions or reorganizations which are simply internal reshuffles, it would take a powerful case of net social gain to justify denying such treatment. Indeed, even if imvestors have no reason to expect unequal treatment, nothing short of an explicit warning of that risk in advance of investinent would justify exposing thein to it.

pean Companies by the Commission of the European Communities. See Commission of tuE European Communities, Proposal for a Council Regulation Embodyino a Statute for European Companies art. 46 (1970), reprinted in 3 Bull. Eur. Communities Supp. at 44 . Cf. Department of Trade, supra, at 6-8. 
II

\section{THIRD Party TRANSACTIONS}

\section{A. Arm's-length Mergers}

In the case of arm's-Iength mergers, in contrast to parent-subsidiary mergers, the problem centers less upon the price paid by the acquiring company than upon equality in distribution among the shareholders of the company being merged out. But price is not irrelevant in considering the problem of equality. If assuring the division of an otherwise fixed purchase price were the only consideration governing the application of the equal treatment principle in the context of arm's-length mergers, there would be no more reason to dilute the principle in that context than in the dividend or liquidation context. But to some extent, the purchase price and the consummation of some mergers may be affected by enforcement of a rule of equal treatment. From the minority stockholder's point of view, the question is whether he is likely to fare better if the law assumes, or indeed permits, disproportionate sharimg of the purchase price than if it does not. And from society's poimt of view, the question is whether such a rule is more likely to effect optimal allocation of resources-i.e., transfer of property to more productive uses - than a rule of equal treatment.

The problem of disproportionate distribution of the merger proceeds among stockholders is not significant in negotiated mergers between corporations not having controlling stockholders and where neither corporation solicits purchases of the other's stock. In such cases, any problem of impropriety in the distribution of the purcliase price derives largely from side payments to management. But the propriety of the distribution of merger proceeds to stockholders frequently arises (1) in negotiated transactions where the acquired corporation has controlling stockholders; and (2) in two-step mergers where the acquiring corporation starts by seeking from the public a control block of the target's stock.

\section{Mergers After Negotiated Sales by Controllers}

The essential objection to the rule of equality in the case of an arm's-length merger is that it creates the possibility that buyers inust pay more for $100 \%$ of the assets than a disproportionate sharing rule would require. And to the extent that the buyer must pay more, a certaim number of desirable acquisitions will be inhibited-to the disadvantage of minority stockholders and society generally. This may be illustrated by an enterprise that has 1000 shares outstanding in which Mr. X owns 501 shares. Its shares are selling at $\$ 20$ per share, and a buyer with a better use for the business wishes to pay $\$ 22,000$ for the 
entire enterprise. A premium of $\$ 2$ per share to each stockholder is not enough, however, to induce $\mathrm{Mr}$. $\mathrm{X}$ to sell to the buyer. The buyer can offer $\$ 22,000$ and the majority can keep $\$ 11,773.50$ (a $\$ 3.50$ preinium) and force the minority to accept approximately $\$ 20.50$ per share. Or the buyer can offer to pay the controller $\$ 23.50$ for his shares and the $\$ 20.50$ for each of the minority's shares which the controller acquires from the minority. If the buyer does not wish to pay more than $\$ 22,000$ and the rule of equality applies, the transaction will not be consuminated and both society and the minority will be the losers.

As $m$ the case of parent-subsidiary mergers, it is said that $m$ order most efficiently to encourage and effect the gains from such arm'slength mergers, governing law should permit the seller's stockholders, at the discretion of the seller's controllers, to share disproportionately in the proceeds but on a "no worse off" basis. ${ }^{133}$ Central to that prescription is the suggestion that ex ante rational investors should consent to such disparate treatunent.

That suggestion is somewhat, but not anuch, more persuasive in the arm's-length context than it was in the parent-subsidiary context. Market imperfections that create prices favorimg imsiders in anticipation of a merger may not be so frequent or so significant in the case of arm's-length mergers as im the case of parent-subsidiary mergers. Some such imperfections are not unlikely, however. Controllers' efforts to raise, or keep, a market price up to full value can be muted if they perceive an advantage to themselves in doing otherwise. Therefore, to some indeterminate extent, a rule of disparate sharing would produce not inerely an unequal allocation of the inerger's gams, but also actual losses for minority stockholders.

If investors understand the full import of the possibility of unequal treatment, they will increase their price for the imitial mvestment. ${ }^{134}$ Moreover, to the extent that at any given time public investors inust be concerned about whether controllers contemplatimg purchase of minority shares are holding down the market price of the stock in anticipation of a sale of all of the assets, a rule of disparate distribution adds a further cost. Buyers and sellers will face a market price which is im part a function of a discount for risks which do not enter into the present value of the corporate earnings stream. Market prices will, there-

133. That position implies that it is permissible for the controllers to buy up the noncontrollers' stock at the prevailing market price, notwithstanding the controllers' "inside" knowledge (and the noncontrollers' ignorance) of a higher offered price.

134. In theory, that mcrease in the cost of capital can be avoided or reduced by diversification. But in a less than perfect world, adequate diversification by investors is not achieved by many investors, and in enterprises which are, or becone subject to, a private control group, it will not occur costlessly. See supra note 27; text accoinpanying notes 81-84. But cf. Toins, supra note 94, at 560-64 (distinguishing the case of two-step acquisitions initiated by a sale of control). 
fore, be distorted unnecessarily; unless imposing those risks and distortions is necessary to achieve a social gain which offsets the costs.

In general, the gains froin arm's-length inergers should rationally be more substantial than the gains from longtime parent-subsidiary mergers. While the latter simply amalgamate existing joint enterprises, the former embody potential contributions and new uses contemplated by strangers. ${ }^{135}$ But, not all the gains associated with such mergers depend upon allowing diversions to controllers. Assessing the gains that would occur if controllers had a right to divert depends upon tenuous inferences about the incentives necessary to induce wealth-maximizing decisions. Even without a rule of disparate treatment, controllers will sell out to "better" users if the buyers offer enough. The $\$ 2$ premium per share which the buyer offers for $100 \%$ of the stock will often be sufficient for the controller if he is bound by a rule of equality. The uncertam dimensions of the expected gains froin the inerger challenge the necessity for fashioning legal norms so to encourage controllers' acquisitive behavior in an untidy world in which investors can rationally expect not merely deprivation of gains but actual losses.

There is not significantly more reason to think investors should prefer a rule of disparate treatment in arm's-length mergers than in parent-subsidiary mergers or going private transactions. ${ }^{136}$ And there certainly is no more reason to think that they do expect or prefer such open ended disparate treatınent. In the absence of a basis for believing that investors expect such unequal treatment, equity requires a rule of equal treatment ${ }^{137}$ - particularly for the majority of individual investors who are not adequately diversified. ${ }^{138}$

Enforcement of substantive equality would be significantly enhanced by a requirement of formally identical treatment. It is difficult to see any benefits to the acquiring corporation from enabling it to allot different currencies to different stockholders of the acquired corporation. ${ }^{139}$ The acquiring corporation's only productive reason to pay in

135. To the extent that acquirers in arm's-length mergers proceed on less information than do parents, they are more likely to "over pay," but presumably that uncertainty enters into their determination of price. However, the market may not police acquirers so closely that their managers' aggrandizement can be said to be irrelevant in assessing the social value of the transactions. See Marris \& Mueller, The Corporation, Competition, and the Invisible Hand, 18 J. ECON. LirERATURE 32, 40-45 (1980); Note, The Conflict Between Managers and Shareholders in Diversifying Acquisitions, 88 YALE L.J. 1238 (1979); see also M. Jensen \& R. Ruback, supra note 77, at 2-20.

136. See supra notes $49 \& 66$.

137. See supra text accompanying notes 34-39.

138. See supra note 81 .

139. From the point of view of the acquired corporation's stockholders, it is hard to find any reason to permit differential treatment among them in the terms of the merger. If the merger is an all stock merger and some stockholders want cash, they may effect that result by selling the stock of the acquiring company on the market. If cash is the merger currency, it can be used to buy the acquirer's stock. In either case, uniformity of treatment is effected in the merger itself. If the sales 
different currencies is that it needs or prefers to do so in order to acquire the services of either stockholding management or controllers of the acquired corporation. But that purpose can be fully inet by making the side payinents explicit, identifying the amounts and the services or other goods acquired, and justifying the extra payments as such. ${ }^{140}$

If the principle of equality demands distribution of an identical form of currency to each stockholder of the acquired corporation, nothing in the governing law precIudes it. The fact that the statutes in all states contemplate payment of cash or other kinds of property (bonds, preferred stock or real assets) to the stockholders of an acquired company ${ }^{141}$ does not mean that they contemplate differential payments to the acquired company's minority stockholders. The statutes were enacted to facilitate mergers by permitting an acquiring company to pay in a currency other than its own cominon stock. ${ }^{142}$ For many purposes, it may be desirable to use bonds or cash to eliminate all the stockholders of the old company. It does not follow from the need for such flexibility that there is a need to differentiate among the stockholders of the acquired company. The statutory language is met if all members of the class are required to accept, and an acquiring corporation is required to pay them, the same form of currency. ${ }^{143}$

\section{Two-step Takeovers}

The problem of equality of treatment in a merger, which is the second step after a successful tender offer for control, is somewhat dif-

or purchases impose intolerable or undesirable additional costs upon the public stockholders of the merged enterprise, the acquiring company may offer them the option to take cither stock or cash as they choose. But to offer individuals the option of selecting different forms of payment presents none of the objections applicable to coinpelled receipt of different forms of payinent.

140. If the value of the common assets is affected by the continuance of the services rendered by the controlling shareholder, the problein of disentangling the value of the controlling stockholder's continued services froin the value of the enterprise without thein (which is the only value on whicl the minority has equal claims) is not solved by the form of currency used. Nor does the form of currency used avoid the possibility of thus creating a screen which conceals disproportionate payinents extracted by the refusal of the controlling stockholder to consent to the inerger unless thus bribed. Bnt while both those problems present difficulties for administering the rulc of equality in sharing the proceeds of the merger, neither requires or justifies departure froin that rule in substance.

141. See, e.g., MODEL Business CORP. ACT $\$ 71(c)$ (1979).

142. See Weiss, supra note 41, at 632-41; Brudney, Going Private, supra note 52, at 1028; Greene, supra note 42 , at 489 n.7.

143. It does not detract from this conclusion that the same statutory language when invoked in the context of parent-subsidiary inergers permits formally different treatinent of parent and public stockholders. In that context, the parent as stockholder of the subsidiary is, by definition, acquiring the assets of the subsidiary and the public stockholders of the subsidiary are, by definition, acquiring either stock of the parent or other currency. Sucl differentiation is unavoidable. See supra note 69 . But the inevitability of differentation in parent-subsidiary mergcrs does not require or support differentiation in the distribution of the proceeds of single-step arm's-length mergers among the acquired company's stockholders. 
ferent from the problems encountered in either longtime parent-subsidiary or negotiated arm's-length mergers. ${ }^{144}$ The purpose of equal treatment of the target's stockholders in two-step takeovers is not so much to avert unequal division between public investors and the target's controllers (smce by assumption there are no controllers) but to prevent the bidder from taking advantage of the power of a single offeror to whipsaw dispersed offerees. The question is whether to allow the bidder to pay less in the coerced second step even though doing so restricts, or indeed denies, the free choice investors are assumed to, and led to believe they do, have in the first step.

It has been urged ${ }^{145}$ that the costs of a rule of equality in two-step takeover transactions outweigh its gains. The argument is that a rule of equality would imcrease the cost of, and lience discourage soine, takeovers. To the extent that the principle of equality encourages holdouts in response to the tender offer, it will inake the takeover less likely to succeed and nore costly. Two undesirable consequences follow. More productive use of assets by the acquirer is impeded, and the disciplinary effect of the takeover market is diminislıed. Moreover, since premiums are always paid on takeovers (in anticipation of inore productive use of assets), to discourage takeovers is to make all public investors in potential targets poorer.

The opposing argument is that even if takeovers enhance social utility to some disputed extent, the costs of allowing the acquirer to coerce shareholders into yielding their property are too high. Arguably, the dispersed stockholders are paid less in the takeover than a single knowledgeable seller would be willing to accept. ${ }^{146}$ Since dispersed shareholders lack the bargaining capacity of a single owner of a majority of the stock, the bidder's price is likely to be less than the "ideal" market price. ${ }^{147}$ To permit the price in the second step merger of a unitary transaction to be lower than the tender price is to further reduce the sellers' price option.

The positive attraction of the bid price is the normal inducenient

144. No functional bright line can be drawn to offer an easy operational distinction between a merger contemplated as a second step at the time control was acquired and a merger which was not so contemplated but is stimulated by events after the acquisition of control. A rule of thumb is feasible, however. See Brudney \& Chirelstein, Mergers and Takeovers, supra note 41, at 340 n.87. For analytic purposes we may treat the former as a unitary transaction quite distinct in kind and in appropriate conseqnences from the latter.

145. See, e.g., Easterbrook \& Fischel, supra note 66.

146. See Lowenstein, supra note 27; Toms, supra note 94.

147. Two-step tender offers and negotiated mergers represent fundamentally different bargaining processes. See Brudney \& Chirelstein, Mergers and Takeovers, supra note 41, at 340 n.89; Brudney \& Chirelstein, Corporate Freezeouts, supra note 41, at 1363-64 n.18; Toms, supra note 94, at 554-60. 
to a seller. If the bid price is not high enough to induce a majority of investors to accept it without the pressure of the threat of a later coerced lower price, then it is likely to be less than a seller acting for the entire constituency would accept. ${ }^{148}$ If stocks of publicly held corporations sell on the market at less than would $100 \%$ of the stock of a private corporation, it is presumably in part because of agency costs. To press a takeover bidder to offer a price approaching what a private owner would hold out for ${ }^{149}$ is to seek to allocate to public investors some but not all of the savings in agency costs which the bidder thinks it can effect. A rule allowing public investors to be whipsawed exposes them to demial of any part of the savings of agency costs; it thus penalizes them in the name of a claimed (but hardly demonstrated) ${ }^{150}$ effort to reduce those agency costs for all investors.

It is not clear whether that whipsaw pressure, and consequent dimimution of dispersed shareholders' bargaining power, creates a cost to society greater than the benefit of allowing a cheaper takeover price, more frequent takeovers, and the claimed closer monitoring of agency costs. The benefits are, a priori, more problematic than the costs. That the increase in the cost of capital resulting from such a takeover regime could be reduced by diversification does not eliminate the problem, at least for the many investors who in fact are not diversified ${ }^{151}$ - even

148. Takeovers opposed by management produce higher prices than unopposed takeovers. See Gilson, A Structural Approach to Corporations: The Case Against Defensive Tactics in Tender Offers, 33 Stan. L. Rev. 819, 868 (1981). See also Carney, supra note 42, at 112-18 (suggesting possibility of loss to aggregate of target shareholders from price of successful bid for $51 \%$; $\mathrm{S}$. Linn \& J. McConnell, An Empirical Investigation of the Impact of the Antitakeover Amendments on Common Stock Prices, (June 1982) (unpublished manuscript forthcoming in volume 11 of the Joumal of Financial Economics); H. DeAngelo \& E. Rice, Antitakeover Charter Amendments and Stockholder Wealth (June 1982) (unpublished manuscript forthcoming im volume 11 of the Journal of Financial Economics).

149. See Bebchuk, supra note 82, at 48-49; Lowenstein, supra note 27.

150. See Lowenstein, supra note 27; Gilson, supra note 148, at 870-75. The sizes of the premiums offered on takeover bids prior to the impact of the Williams Act suggest rather substantial agency slack in target companies. Possibly all, or even more than all, of the imcrease in the size of the premiums after the Act, see P. Asquith, R. Bruner \& D. Mullins, The Gaims to Bidding Firms from Merger (Nov. 1982) (unpublished manuscript forthcoming in volume 11 of the Journal of Financial Economics), is attributable to the impediments generated by governmental intervention and by new defensive tactics. But the notion that the threat of takeover significantly reduces agency costs is not self-evident. In the absence of evidence showing that premiums have contracted despite the volume of takeovers during the past 15 years, particularly during the last seven or eight years of the takeover movement (i.e., simce the bulk of the governmental intervention has become effective), the salutary effect of the takeover movement on reducing agency slack remaims uncertain and undemonstrated - and so do the cost-benefit conclusions of the protagonists of compelled passive responses by target managements to takeover bids. Doubts about the validity of the notion that "better" uses systematically displace "worse" uses in takeovers are not allayed by the recurrence of takeovers like the U.S. Steel acquisition of Marathon Oil or the Martin-Marietta, Bendix, Allied fasco. See N.Y. Times, Oct. 3, 1982, at 37, col. 1; Lowenstem, supra note 27, at 289-94.

151. See supra text accoinpanying notes $69-89$. 
assuming it is appropriate to fashion legal rules that penalize failure to diversify against such contingencies.

Nor would a rule of equahty impose undue costs on investors, notwithstanding the claim that potential tenderers will lose opportunities for premiums because a rule of equality will discourage tender offers. The cost of that loss must be assessed against the amounts lost (i.e., the difference between tender price and merger price) by those who fail to tender under a rule which permits disparate payinent. ${ }^{152}$ Those lost amounts may be lessened, but will not be eliminated, if the merger price exceeds the pre-tender-offer price, as it is said inevitably to do. In any event, it is not clear why an investor would rationally consent to invest under a legal arrangement permitting such a whipsaw, even with a pre-tender-offer floor, if he were given the opportunity to accept a rule of equality-notwithstanding that the rule of equality might produce fewer tenders at prices that were uniform as between each of the two steps. ${ }^{153}$

It is less clear in a two-step merger than in a single step merger that investors expect equal treatment. While an inference of such expectation is reasonable in the case of a negotiated first step, there is room to question that inference when the first step is a public tender offer. In the latter case, the premise of equal treatment with a controller is absent. However, even if there is little to establish that equality of treatment in the second step is actually an expectation of investors generally, $\mathrm{m}$ most circumstances there is not yet a basis for concluding that inequality of treatment is their expectation. In the context of sucli ambiguity, the absence of a requirment of explicit warning in advance of mitial investment leaves little reason to deny a requirement of equal payment on the second step on the ground that it is not expected.

Moreover, there is good reason to impose sucl a requirement in view of the assumption of unhampered, if not uncoerced, free choice by the offeree as the condition which validates the takeover-bid price-

152. Disparaties in the ability of offerees to respond to tender offers, Nathan \& Volk, Developments in Acquisitions and Acquisition Techniques, 12 INST. ON SEc. REg. 178, 181-82 (1981); Welles, Inside the Arbitrage Game, Institutional INVESTOR 41, 46-51 (Aug. 1981), raise the further question of unequal distribution of the inerger proceeds between sophisticated and unsophisticated investors. That question is not merely academic, as is shown in the SEC proposal to extend the tender period for two-tier tender solicitations. See Securities Exchange Act Release No. 19,336, [Current] FED. SEC. L. REP. (CCH) If 83,306 (Dec. 15, 1982) (promulgation of SEC Rule 14d-8 regarding prorationing of tender offer pools); SEC Tender Offer Committee: Agenda of Major Issues Established During First Meeting, CoRp. L. GuIDE (CCH) No. 634, at 6-7 (Apr. 12, 1983) (discussion of problem before SEC advisory committee on tender offers); Bebehuk, supra note 82 , at 46.

153. Whatever may be the validity of objections to managerial efforts to obstruct tender offers even if those efforts are made solely in the interests of stockholders, see supra note 145, those objections do not apply to a rule of uniformity of price that is designed to prevent a whipsaw of dispersed investors. 
both as a matter of fairness and as a matter of efficiency. That condition is eroded if the coerced second step price can be lower than the tender-offer price. ${ }^{154}$

\section{B. Sales of Control}

Even if the principal of equahty should cover all transactions in which minority stockholders receive distributions or acquire different participations in a corporation, the question remains whether it also should cover transactions which entail no more than transfers by controllers of their controlling shares to third persons. Fornally, the minority shareholder's participation is unaffected by the transaction, so that there is no occasion to inquire about equal treatment. From a less fornal perspective, however, although the minority has neither acted nor received a different certificate or form of ownership, it is participating in the corporate enterprise differently than is the controller and than it did before the transfer. The controller now has cash and is "out" while the minority continues to hold stock and is " $\mathrm{m}$."

To be sure, the same description fits all stockholders of all public corporations at all times. Some stockholders sell and are "out" with cash, while others remain " $\mathrm{m}$ " with stock. There is a significant difference, however. To the extent that a transfer of control results in a new controller-manager, the enterprise is no longer the same. The minority, without its consent, is participating in a different enterprise as certainly as if there had been a merger with a third party. And it is not being treated equally with the former controller in this effective merger. The minority is now being frozen in, imstead of frozen out. Its continued participation in the risks of the new enterprise may or may not have a present value economically equal to the cash received by the controller. It is difficult, if not impossible, to tell. Certainly im form, equal treatment is not beimg accorded. The question is whether either formal or substantive equality of treatment should be required im such circumstances.

Judicial opimions often fail to see the problem as involving a rearrangement of investor participations in the corporation-for which a

154. To assure precisely equal treatment would require not merely payment of the same sum per share on the second step as on the first, but also compensation for the delay, in the form of an appropriate return on the delayed payment. While such precision would be appropriate if the problem were the propriety of controllers' diversion of some portion of the purchase price from pubhic investors, there is less reason to insist upon such meticulous equahity when the recipients of the first payment are themselves dispersed public investors who bear no responsibility for any disparity resulting from the delay in payment. And the size of that disparity is limited by the limited duration of the period between the two steps which is a tolerable condition of finding a unitary transaction rather than a long-term parent-subsidiary merger. For the latter, equality is measured on a common stock basis rather than by the tender price. 
rule of equal treatment would be required. Instead, they are tinctured by a concern with the property rights and hiquidity of the controllers as owners of shares of stock. Subject to the tort restriction agamst an act (i.e., the transfer) which injures other stockholders, controllers' freedom to dispose of their personal property at whatever price they can get ${ }^{155}$ has remamed a predominant factor im sale of control cases. ${ }^{156}$ From that perspective, there is no need to assess the unequal consequences to investors of a single transaction in the cominonly owned corporate assets. The courts' failure to perceive the sale of control as a transaction which alters and to some extent thereby sells some of every imvestor's participation in the enterprise may reflect judicial myopia. But the rationale of the opinions with that view does not deny that a rule of equal treatment for imvestors should prevail if the transaction were seen as a rearrangement of everyone's participation in the enterprise. ${ }^{157}$

Nor does the property-based rationale establisli the principle that ownership of control entitles the controller to better treatment than other stockholders in the distribution of corporate assets. ${ }^{158}$ It is principally academics who see the cases as establishing that proposition. ${ }^{159}$

155. See Clagett v. Hutchison, 583 F.2d 1259 (4th Cir. 1978); McDaniel v. Painter, 418 F.2d 545 (10th Cir. 1969); Perlman v. Feldmann, 219 F.2d 173, 178 (2d Cir.) (Swan, J., dissenting), cert. denied, 349 U.S. 952 (1955); Ritchie v. McGrath, 1 Kan. App. 2d 481, 571 P.2d 17 (1977); Tryon v. Smith, 191 Or. 172, 229 P.2d 251 (1951); $f$. Yerke v. Batınan, 176 Ind. App. 672, 376 N.E.2d 1211 (1978) (duty of seller is to corporation, not to its remaining stockholders). But $c f$. Zetlin v. Hanson Holdimgs, Inc., 48 N.Y.2d 684, 397 N.E.2d 387, 421 N.Y.S.2d 877 (1979) (valid interest of controller in the premium derived from corporate control).

156. See Gerdes v. Reynolds, 28 N.Y.S.2d 622 (Sup. Ct. 1941); Perlman v. Feldmann, 219 F.2d 173, 178 (2d Cir.) (Swan, J., dissenting), cert. denied, 349 U.S. 952 (1955). Even in such cases, the vision of stock as fully transferable personal property seems to impel courts to narrow the seller's duty to ascertain (or even to note) the buyer's tortious potential to injure the corporation. See, e.g. , Swinney v. Keebler Co., 480 F.2d 573 (4th Cir. 1973); Levy v. American Beverage Co., 265 A.D. 208, 38 N.Y.S.2d 517 (1942).

157. Cf. Seagrave Corp. v. Mount, 212 F.2d 389 (6th Cir. 1954); W. CarY \& M. Eisenberg, supra note 3 , at $683-88$.

158. But $c f$. Zetlin v. Hanson Holdings, Inc., 48 N.Y.2d 684, 397 N.E.2d 387, 421 N.Y.S.2d 877 (1979). The form in which the cases generally reach the courts-a request by the minority for equal sharing of the controller's premium-suggests that a denial of the plaintiff's claim is a denial of a rule of equal treatinent. But, if the denial of equal shares in the premium is based upon a view of the transaction that does not see any common involveinent of all stockholders, or even of all the corporate assets, in the transaction, what is denied is merely the nonseller's right to participate in the proceeds of a transaction in personal property in which the nonsellers have no interest. There is no denial of a right to share equally in the proceeds of the sale of corporate assets.

159. See, e.g. , Toms, supra note 94, at 560; Easterbrook \& Fischel, supra note 8, at 715-16; see also Chazen, supra note 71 , at 1467-70. To academics, who tend to view the transaction inore broadly as a transfer of some interest of the nonsellers in the corporation, inequality in the division of the premium also may not mean that the minority is not (except in form) denied equal treatment or that they are not entitled to it. The buyer is presumed to expect a higher value for the corporation than its market price, and a higher value even than the premium price. While academics are fuzzy about the present value of that expectation, such an expectation (and an aura of corporate value at around the premium price) is their bedrock premise. See Easterbrook \& Fis- 
And they go on froin there to argue that that proposition undermines the rule of equal treatment in inergers, if not also in hquidations. ${ }^{160}$ The question they pose in the sale of control cases is whether the cost of departing froin a rule of equality (in substance, not inerely in form) is worth the gains it offers to investors and society.

If no increase in the value of the enterprise were envisionable from the sale of control, the only reason to permit departure froin the primciple of equality would be to protect the controllers' freedoin to transfer his stock. If the transfer offered no possibility of enhancing enterprise value, the only reason for the buyer to pay a premiun would be to appropriate soine portion of the minority's assets to itself. There is little more rational basis for permitting such premiums to be kept by sellers than for permitting such appropriation by buyers.

Accordingly, the essential justification for permitting departure from a rule of equahity is the probability of an increase in enterprise value coupled with the necessity for such a departure in order to enhance that probability. That rationale is only a justification, however, if the benefits to minority stockholders and to society from the probability of an increase in enterprise value exceed the costs of a rule of disparate treatinent.

To the extent that the probability of increasing enterprise value

chel, supra note 8, at 705 . Without it, they would be hard pressed to justify either such a sale of control as a rational ex ante expectation of a pubhic investor, or a rule allowing the premium.

160. See Easterbrook \& Fischel, supra note 8, at 705, 715; Cohn, Tender Offers and Sales of Control, 66 Iowa L. ReV. 475 (1981); W. CARY \& M. EISENBERG, supra note 3, at 683-88. The circularity of arguing from a rule allowing controllers a premium on sale of control to a rule of disparate sharing in distributions and inergers is matched by making the contrary argument in the reverse order. But the circle can be broken. Premiums extracted by sellers in simple sale of control transactions rest on the controller's ability to capitalize his power to enjoy perquisites while in control because the fiduciary or contractual rules prohibiting such perquisites are not rigorously enforceable. It by no ineans follows from a rule permitting the controller to keep those premiums that disproportionate division is appropriate in either two-step ann's-length inergers or in purely internal reshuffles such as parent subsidiary mergers or going private transactious. The absence of third-party valuatious and contributions, and the presence of self-dealing, make the latter two cases entirely different from sales of control. And the fact that in arm's-length mergers minorities are formally forced to accept different claims with different tax and investment consequences justifies an accounting by the controller, in conformity with the minority's contractual expectations. That justification for requiring an accounting is absent in a simple sale of control. On the other hand, the premises on which a rule of equality rests in internal reshuffes and arm's-length mergers are powerful enough to support, if not require, a similar rule with respect to premiums in sales of control.

The limitations on the effective application of fiduciary strictures on controllers' diversion of assets during continumg operations should not become the basis for creating property rights in the capitalized value of those limitations or for declining easy applications of those strictures on sale or reorganization of the enterprise. Such application of those strictures to control transactions certainly would not discourage, and might well encourage, intproved effectiveness of the fiduciary rules as they apply during continuing operations. 
turns on encouraging buyers to bid, Andrews ${ }^{161}$-and the tender offer inovement-have deinonstrated that there is no need to depart from the rule of equal treatment in order to induce buyers to seek to acquire a controlling interest. If all that a buyer seeks is control, he can acquire it by tender offer. without departing from the rule of equahity. There is no reason to beheve that the cost to the buyer in a tender offer will systematically be any higher than the cost of a negotiated sale by a knowledgeable controller. Dispersed stockholders are not in a position to extract a higher price (i.e., to negotiate with the buyer) than would a controller. ${ }^{162}$

Whether the likelihood of a transfer of control (and a presumably better use of the enterprise's assets) is significantly changed if the controller cannot get a premium is another question. ${ }^{163}$ That the controller is inore likely to sell if he is allowed to keep a higher price than if he were required to share "equally" with the public stockholders nay be conceded. If not just greed, then a felt entitleinent to capitalize the perquisites of continumg control will stimulate an interest in a premium. To defer to the controller's desire to be paid the capitalized value of the improper agency perquisites in order to induce a new agent to reduce agency costs hardly suggests that agency costs will in fact be reduced. Nor does it suggest that public investors will be encouraged to invest. ${ }^{164}$

It is not self-evident that the cost to the minority of allowing a controller so to exit and turn over control of the minority's assets is less than the benefit the minority and society nay gain froin allowing the new controller so to enter. There is ample rooin for debate over how

161. Andrews, The Stockholder's Right to Equal Opportunity in the Sale of Shares, 78 HARV. L. REv. 505 (1965).

162. But of. Easterbrook \& Fischel, supra note 8, at 705 (tender offer more costly than private purchase of control).

163. See Javaras, Equal Opportunity in the Sale of Controlling Shares: A Reply to Professor Andrews, 32 U. CHI. L. Rev. 420 (1965); Manne, Mergers and the Market for Corporate Control, 73 J. POL. ECON. 110, 116-17 (1965).

164. If agency costs can be said to reflect the advantages to agents of both diversion potential and "quiet life" potential, the premium paid to the controller is likely to reflect more significantly the benefit to the acquirer of the potential for unpoliceable diversion that the controller is giving up. But the successful acquirer is not likely to sacrifice that potential in the imterest of the remaining public stockholders. There is no reason to believe that if the acquirer should reduce or eliminate the cost to the public of the "quiet life" potential it will be by amounts that will offset, let alone exceed, the cost of the continued diversionary potential.

It is possible for an acquirer to pay a small premium (e.g., 10\%) for $50 \%$ of the stock of a corporation, not in the expectation of "improper" diversion but in the belief that better management will increase the aggregate value of $50 \%$ of the stock by more than the amount of the premium. But to the extent that such an expectation implies some indeterminate reward to the buyer for his managerial and entrepreneurial talents, it affects the likelihood of a sufficiently large imcrease in the aggregate value of the enterprise to give the nonsellers the equivalent of the premium received by the seller. 
that question is to be answered systematically. But there is no doubt that sale of control to a buyer who, by definition, is not seeking $100 \%$ ownership leaves the minority with the possibility of a loss, not merely with a disparate sharing of a gain. And a controller who can exit totally does not search for either the nost honest or the inost efficient buyer, even if he is constrained by a duty of care. Therefore, the remaining stockholders are put at risk by a seller who systematically looks to his own rewards but ignores the interests of others. To that extent, whether viewed ex ante or ex post, ${ }^{165}$ departing from a rule of equality is less attractive to a risk averse investor than exposure to the forced merger at a price no less than the inarket price preceding a successful tender offer or negotiated purchase of control.

In sum, considerations both of fairness and efficiency support a rule of equal treatment for the stockholders of corporations whose control is transferred to third parties. Such treatınent requires that a buyer who is prepared to pay a premium for purchase of control, but not for $100 \%$ of the enterprise, should offer the premiun to all stockholders pro rata, or the seller should divide the premium with the reinaining stockholders; if a buyer pays a premium for control and, in a unitary transaction, acquires the balance of the target's stock, the buyer should pay the noncontrolling stockholders the same price per share paid for control. ${ }^{166}$

III

\section{Collateral Benefits}

The rule of equal treatinent also has implications for the division of those gains from corporate dividend policy, niergers, or control

165. Hill, The Sale of Controlling Shares, 70 Harv. L. Rev. 986, 1033-34 (1957); Note, The Right of Shareholders Dissenting from Corporate Combinations to Demand Cash Payments for Their Shares, 72 HaRv. L. Rev. 1132, 1144-45. Cf. supra note 19. The ability to diversify the risk of such a sale of control, see supra notes $23 \& 82$, is not so clear as to preclude the question whether the increased cost of capital would be wasteful.

Whether a seller of control should be obliged to accept a smaller premium from a buyer seeking all the stock and forbidden from accepting a higher premium from a buyer seeking only control, see, eg., Blackinon v. Carson, 65 A.D.2d 731, 410 N.Y.S.2d 294 (1978), presents another question. Since the controller is not obliged to sell at all, one alternative for him is to hang on if he is not satisfied with the smaller premium. Cf. Jones v. H.F. Ahmanson \& Co., 1 Cal. 3d 93, 115-18, 460 P.2d 464, 476-78, 81 Cal. Rptr. 592, 604-06 (1969) (controllers need not go public in a coerced rcorganization if doing so deprives minority of opportumity to participate in advantages of publicly marketed stock). But see Toms, supra note 94, at 571-72. There is little reason to believe that a seller who wishes to exit will often hang on rather than take a smaller-i.e., sharedpremium.

166. To the extent that the successful bidder's offering price can be said to undercompensate the target's stockholders, see Lowenstem, supra note 27, all of them-tenderers and nontenderers alike-are disadvantaged. It is not obvious that an appropriate remedy for that disadvantage need permit inequality of treatment of the two classes. A different question is raised if the merger is not a unitary transaction. 
transactions which do not technically become corporate assets, but instead benefit individual stockholders separately. Personal gains, such as tax benefits or portfolio diversification, may vary from investor to investor not by reason of the corporate action's impact on the value per share of stock but by reason of its impact on the individual investor's wealth position. ${ }^{167}$ Whether the import of a rule of equal treatment for gains resulting from such corporate action should be to require the decisionmaker to focus on increasing corporate wealth rather than on increasing the aggregate personal wealth of individuals is a question that raises a number of subsidiary issues. Its significance is considerably diminished, however, if parts of the controllers' personal wealth increment can be transferred to the minority stockholders by requiring the controller to account to the corporation for benefits he received from the transaction which were not reflected in increased corporate wealth.

There are good reasons to confine corporate decisions or uses of corporate assets to efforts to maximize, and share, the collective worth of the firm. Other increases which such decisions or uses produce in the aggregate personal wealth of individual shareholders are a inatter of separate concern. Considerations both of equity and of efficiency support such separation.

So far as equity among stockholders is concerned, if investors with diversified portfolios own stock in a particular company, solne of thein will almost certainly be affected differently from others by particular corporate distribution or reorganization decisions. Indeed, in view of the multiplicity of personal variations, no rational investor would expect his personal wealth preference to determine such corporate decisions unless all stockholders held the same preference. For soine kinds of corporate action, such as dividend policy, an acceptable but not necessarily optimal or enforceable solution is offered by the possiblity that chenteles of investors will form for particular companies with particular policies. ${ }^{168}$ For other decisions, such as desired inerger currencies or terms, a "clientele" solution is not feasible. Only by attending to the

167. See supra note 10.

168. See Fischel, supra note 126, at 704-06. If an investor's personal preference is for retained earnings (or dividends) for tax reasons or otherwise, he can sell one stock and find other investments whose dividend policies satisfy his need. Such personal flexibility requires adequate information about dividend policy, or other relevant corporate policies. While determination of the "adequacy of information" raises difficult issues, those issues are not immediately relevant.

This solution is acceptable and optimal on the assumption that dividend policy follows from investment decisions made to maximize enterprise values. The difficulty of determining in court the pnrpose of the controllers' investment decision leaves an umbiguity in the assumption that makes the solution difficult to enforce. Moreover, if the assumption is false, the solution is not optimal. Comparable problems of enforcement arise if dividend decisions can be made to maximize share values but not necessarily enterprise values. 
impact of a decision on the value of the corporate assets or collective proceeds can management avoid systematically frustrating one group's interests for the benefit of another's. Any differential impact on individual stockholders from an announced policy of attending to collective value may properly be seen as fortuitous and not an unfair use of corporate assets.

The matter is more complex with respect to optimal resource allocation. Generally, on standard free market assumptions, and certainly in the absence of a feasible system of transfer payments, it is the impact of a corporate decision on the firm's return per unit of risk, more than its impact on the varied configurations of shareholder wealth, that is most likely to produce optimal use of the firm's resources. If management is confined to the task of enhancing collective wealth (and majority stockholders are similarly confined) in the exercise of their power or discretion with respect to the use of corporate resources there will presumably be a larger corporate pie to divide. ${ }^{169}$ Efforts to tailor corporate actions to the varied configurations of investors' personal wealth suffer from the same difficulties and perils as efforts to use corporate assets to meet investors' other personal preferences. ${ }^{170}$ They pose problems im the relationship of individual choice to collective action. ${ }^{171}$ A focus on increasing material wealth (rather than satisfying varied nonpecumary preferences) mitigates the severity of those problems. But even so, a rule permitting deference to personal wealth preferences of majorities will mevitably generate bundling costs. ${ }^{172}$ To avoid those costs requires decisions about the enhancement of personal wealth to be left to individual investment adjustments, mstead of permittimg such considerations to affect collective decisions on the use of commonly owned assets.

On the other hand, it is possible that control or merger transactions or dividend decisions will increase aggregate stockholder wealth, notwithstanding the failure to increase corporate wealth. Each stockholder may share in the increment if the controller is required to make transfer payments to the minority by accounting to the corporation for his gam and their loss. The matter is further complicated because corporate transactions that produce collateral personal benefits for the

169. The stated obligations of directors and officers to "the corporation," see supra note 3 , rather than to particular stockholders accords legal recognition to the primacy of enhancing collective wealth if collective assets are being used.

170. See, e.g., Brudney, Business Corporations and Stockholders' Rights Under the First Amendment, 91 Y ALE L.J. 235 (1981); Engel, An Approach to Corporate Social Responsibility, 32 StAN. L. REv. 1 (1979).

171. See supra note 11. To be sure, the existence of a single controller reduces the significance of those problems.

172. See Brudney, supra note 170 , at 264-65. 
controller but not for the minority-e.g., a leveraged buyout or a merger for stock of one acquirer rather than for more cash from another bidder-may or may not optimally allocate resources. ${ }^{173}$ Whether or not a rule that requires controllers to share their personal benefits or a rule that permits them to appropriate collateral gains has any effect on the appropriate allocation of resources, no less favorable results are likely to follow from a rule requiring sharing than from a rule that does not. ${ }^{174}$ And it will cost less by way of investor uncertainty and the resulting impact on the cost of capital. ${ }^{175}$

Equality of treatment as the measure of sliaring might be implemented by requiring the controller to account for the ainounts that the minority would have received if the controller had focused solely on maximizing corporate wealth; or it might be implemented by requiring the controller to share all his personal gains. When the decision maker (whetlier controlling stockholder or hired manager) has no collateral

173. Thus, for example, consider the case of ESS corporation. Its stock sells at $\$ 70$. Competing bids are being made for its assets: AMP corporation offers cash in the amount of $\$ 100$ per share and BOX corporation offers its stock (share for share) which has a current market price of $\$ 90$ per share. The holder of 51 percent of ESS stock prefers the BOX offer because his low tax basis for his ESS stock makes BOX's stock worth more to him than AMP's stock. If tax policy is put aside, AMP's higher price presumably (but not necessarily) refiects a potential better social use of the property than BOX would inake; and by the same token BOX's offer presumably suggests a better use than the controller is presently making. If fiduciary rules require the controller either to accept AMP's offer (because of the interests of ESS's minority in a higher price for the assets) or to decline the transaction, he may rationally opt for the latter. A rule which would permit the controller to make the transaction without accountability would not produce the best social use (as between AMP and BOX) and would disadvantage ESS's minority imvestors with a corresponding social cost. A rule which would require the controller to account would at least tend to further the transfer to a better use than the controller makes and avoid the costs of minority investor uncertainty. In margimal cases, it might not further the transfer (because the cost of the transfer payment might exceed the tax benefit to the controller), but it would be no less efficient than a rule of nonaccountability.

174. See supra note 173. Since, by definition, the mooted uses of corporate assets will not subject the controller to any special risk that does not also affect the other investors, no added incentive to make such uses need be given to the controller. And the consequence of any such use is to create a likelihood of failing to maximize the size of the corporate pie, and rarely (e.g., dividend withholding) any likelihood of increasing its size. Hence, prohibiting the transaction or requiring accountability for private gains from it will rarely inhibit transactions that are useful to society or to minority investors.

175. Chazen suggests that if in a merger proposal a target is offered $\$ 100$ in cash or, alternatively, stock of the acquirer having a market price of $\$ 90$, the latter should be preferred by inanagement if "thcre is substantial public shareholder interest in a tax free alternative." Chazen, supro note 71 , at 1459 . Whatever may be the case for a disinterested inanageinent, a controller is no more entitled to make that choice than the controller would be to accept an offer of a high premium for himself and reject an offer of a lower premium for $100 \%$ of the stock. See Harman v. Masoneilan Int'l, Inc., 442 A.2d 487 (Del. 1982). But cf. Blackmon v. Carson, 65 A.D.2d 731, 410 N.Y.S.2d 294 (1978). If inanagement negotiates a sale for a cash/stock option at a price less than the price in an all-stock or all-cash deal, that result inay be justified on Solomonic primciples. But that justification would not be equally apphicable if the Solomonic judgment were made by a controlling stockholder. See Schreiber v. Carney, 447 A.2d 17, 26-27 (Del. Ch. 1982). 
personal interest in the result of the decision, it is reasonable to assume he is attempting to maximize corporate values. ${ }^{176}$ But when the controlling stockholder has such a collateral personal interest, as in a leveraged buyout, it is no longer so clear that corporate value maximizing is likely to be the result. To test the noncontrolling stockholders' entitlement by assuming that the controller would have sought to maximize stockholder wealth if he had not been diverted by his own interests, involves a search for what might have been.

In recognition of the intractable difficulties of that search, the legal response is frequently to impose categorical prohibitions of such transactions or a requirement of accountability for personal gains from them instead of merely imposing hability for losses or lost profits. ${ }^{177}$ The propriety of requiring such an accounting and of imposing liability on the controller for losses to the firm ${ }^{178}$ is clearest where corporate assets are diminished by reason of the decision. It is puzzling, but should not detract froin that conclusion, that requiring an accountimg or imposing liability in such cases is far froin uniformly accepted. ${ }^{179}$ Where failure to maximize corporate wealth is genuinely disputable-as in simple

176. To assume value maximizing goals for the enterprise as a predicate for measuring equality of allocations of corporate wealth is not to penalize officers, directors, or controlling shareholders for failure to achieve those goals, as long as they have no collateral personal preference as to the results of corporate action. The duty of care to which officers and directors, and presumably controlling stockholders, are held sets a floor on the required extent of their efforts to maximize enterprise value, on the assumption that they are devotimg all the attention they are required to give to corporate affairs to enhancing corporate value. It does not prescribe sanctions for failure by honest effort to maximize that value. But it predicates the duty of care on the exercise of best efforts so to maximize. If the "best efforts" are compromised by the presence of a collateral personal interest, the modest requirements of the duty of care should cease to be the governing criteria for assessing the propriety of corporate decisions.

177. See Mosser v. Darrow, 341 U.S. 267 (1951); Young v. Higbee Co., 324 U.S. 204 (1945); Irving Trust Co. v. Deutsch, 73 F.2d 121 (2d Cir. 1934), cert. denied, 294 U.S. 709 (1935); see also RESTATEMENT OF TRUSTS $\S \S 205,206$ (1959); $c f$. Arizona v. Maricopa County Medical Soc'y, 102 S.Ct. 2466, 2473 (1982) ("The costs of judging busmess practices under the rule of reason, however, have been reduced by the recognition of per se rules."). These considerations argue for prohibiting leveraged buyouts.

178. See supra note 174.

179. This may be seen from examination of judicial and other comment on corporate decisions in a variety of contexts. Illustrative is the decision to merge for stock (or cash) of the acquiring corporation rather than for a greater present value in cash (or stock). See Chazen, supra note 71, at 1457-58; Harman v. Masoneilan Int'1, Inc., 442 A.2d 487 (Del. 1982). Disclosure of conflicts of interest may be required under the securities laws, but even adequate disclosure does not solve the difficult valuation problems. See Lewis v. Oppenheimer \& Co., 481 F. Supp. 1199 (S.D.N.Y. 1979); In re Spartek Corp., Securities Exchange Act Release No. 15,567, [1979 Transfer Binder] FED. SEC. L. REP. (CCH) \ 81,961 (Feb. 14, 1979); see also Securities Exchange Act Release No. 15,572, [Current] FED. SEC. L. ReP. (CCH) I 24,115 (Feb. 15, 1979). It may also be seen in decisions to waste enterprise value by distributing portfolio securities rather than cash or vice versa, see, e.g. Warshaw v. Calhoun, 42 Del. Ch. 437, 213 A.2d 539, 542 (Del. Ch. 1965), affd, 221 A.2d 487 (Del. 1966); or decisons to buy up stock whose value was depressed by dividend withholding, see Gabelli \& Co., Inc. Profit Sharing Plan v. Ligget Group, Inc. 444 A.2d 261 (Del. Ch. 1982); Berwald v. Mission Dev. Co., 185 A.2d 480 (Del. 1962); or to pay out dividends at the expense of corporate opportumities, see Sinclair Oil Co. v. Levien, 280 A.2d 717 (Del. 1971). But 
dividend withholding - there is less basis for categorically requiring an accounting for personal gains. ${ }^{180}$ And there is even less occasion for such an accounting where the use made of corporate assets (by one form of merger rather than another equally available form) cannot diminish or fail to maximize the enterprise value, even though it $\mathrm{m}$ creases the private wealth of the controlling stockholder. ${ }^{181}$

Any remedy short of a categorical prohibition of collateral benefits implicates procedural safeguards and a variety of forms of relief. Brigading appropriate forms of relief and safeguards with particular transactions or types of transactions is a traditional task for courts. But low that task should be performed and whether legislative or administrative aid is necessary to facilitate its performance are subjects for another inquiry.

\section{CONCLUSION}

There is ample reason to believe that when a publicly held corporation makes distributions or reallocates participations in the enterprise, public loolders of its common stock expect to sliare in the resulting gains equally per share with controlling stockholders. That expectation is not only generated by the normal common stock imvestinent contract, but by the circumstances im which imvestors are induced to buy stock and by the general understanding of the financial commumity.

No less important, that expectation is one which rational imvestors should hold in a world of less than perfect markets. Even if it would be rational for public investors in a world of perfect inarkets to consent to unequal sharing of the gaims but to expect to be no worse off (measured by the market price of their stock) than they were before the distribution or reorganization, the perfect market does not exist for sucli transactions. Controllers' power to affect the market price of stock in anticipation of a distribution or internal reorganization (by withholding information or by manipulation) is apt to make that price systemat-

cf. Schreiber v. Bryan, 396 A.2d 512 (Del. Ch. 1978) (shareholders' derivative suit alleging waste of corporate assets and diversion of corporate opportunity).

180. Hence a controller's decision to withhold dividends must be tested on a case-by-case basis-on whether it is sufficieutly likely to constitute a nse of corporate assets which enhances corporate value. Although it has been suggested that withholding dividends should be categorically forbidden, K. Brewster, The Corporation and Economic Federalism, in THE CORPORATION IN MODERN SOCIETY 72 (E. MASON ed. 1959), such a prescription for the normal course of business confronts insurmountable hurdles, both theoretical and practical.

181. See, e.g., E.I. du Pont de Nemours \& Co. v. Collins, 432 U.S. 46 (1977); Perlman v. Feldinann, 219 F.2d 173, 177 (2d Cir.), cert. denied, 349 U.S. 952 (1955). In such cases, if the controller can show that the enterprise value or the minority's share could not possibly have beeu enhanced by consuminating the transaction im soine other form or by not consuminating it at all, it may be unnecessary to require an accounting. 
ically inaccurate as a measure of the minimuin value to which the public investor is entitled. Hence, there is a fatal flaw in a regime under which controllers are entitled to take nore than their aliquot share of the gains but not more than an anount which will leave public investors no worse off-or even somewhat better off-than market price made them. As economic agents, controllers will seek to take as much as they can, including part of the public's prereorganization value. They can do this because the amount of that value will be recorded by a narket price that they can make disadvantageously inaccurate.

Hence, a rule of unequal sharing is unfair, if only because it frustrates public investors' reasonably induced expectations of equal sharing. It also is likely to be inefficient because it has costs, in teruns both of increased investor uncertamties and therefore cost of capital, and of teinptations to controllers to engage im wasteful transactions in order to effect personal gains. Those costs may well exceed, and certainly cannot be shown to be less than, the gaims claimed to depend upon such a rulc, at least in the case of purely internal rearrangements.

When the rearrangements involve contributions by third parties, such as in arin's-length mergers or takeovers, the gams dependent upon a rule authorizing unequal sharing may be somewhat larger; but, as with internal transactions, the relevant gains are only those that controllers would not accept without disparate sharing. The costs, at least in the case of negotiated mergers or sales of control, are likely to be no less than in purely internal rearrangements. And, given the controllers' unilateral appropriative impulses, they are more likely to be realized than are the expected gams.

To the extent that they rest on investor expectations of equal treatment, considerations of fairness may be somewhat diluted in sales of control or two-step takeovers as coinpared with internal reshuffles. ${ }^{182}$ But there is little reason to believe that investors expect unequal treatment in any of the types of third party transactions. Hence, in the absence of express admonition im advance about exposure to unequal treatment, a rule of equal treatment is preferable in such cases.

A rule of equal treatment is hard to make operational because determining equality of distributions almost inevitably depends upon valuations in judicial proceedings. In that process, the protesting public stockholder is at a significant disadvantage in obtaining and presenting relevant evidence - im terins both of cost and of likely effectivencss. Hence enforcement of the rule is likely to be most effective if it avoids

182. Additional considerations of fairness, not applicable to sales of control, underlie a requirement of equal treatment in two-step takeovers. See supra text accompanying note 154. 
the need for such a valuation process and rehes upon categorical strictures. But if apphication of such strictures is impossible or thought to be too costly, then procedures must be sought to make testing of equality in individual cases more feasible - as by appointing negotiators for the public investors, requiring intervention of administrative agencies, or encouraging more active imtrusion by courts that are able to obtaim expert assistance of their own. 